\title{
A BYZANTINE SETTLEMENT IN KALABAKLI VALLEY IN THE HELLESPONTUS: KEPEZ
}

\author{
AYŞE Ç. TÜRKER*
}

The Hellespont stood out with its geographical location in the production-consumption and shopping relationships between the Aegean and the Marmara regions in the close distance and between the Black Sea and the Mediterranean regions in the long distance in the Byzantine period. The geographical characteristics of the strait displayed three distinct characters. The common feature of the Byzantine coastal cities and settlements in these three regions is that they had a port on the shore of the strait. These ports were generally located at the mouth of the valleys formed by the streams that had reached the Hellespont ${ }^{1}$. We are conducting a project to detect the finds of the Byzantine period and to understand the settlement models on these valleys. The data we obtained from these project studies indicate that the valleys had been densely settled in the Byzantine period. It is understood that one of the densely settled valleys in the Byzantine period was the Kalabaklı Valley (Fig.1) on the Anatolian shore of the middle section of the strait. During our surveys, considerable ceramic and roof covering materials of Byzantine period were documented in Kepez at the northwestern mouth of the Kalabakl Valley². In addition, there are four coins of Byzantine period that were found in Kepez and conserved in Çanakkale Archaeology Museum, i.e. a half follis of Justin II and Queen Sophia ${ }^{3}$ (565-578) (Fig.19.1), a half follis of Leo IV and Constantine VI (775-80) ${ }^{4}$ (Fig.19.2) and two class A2 anonymous folles of Basil II (976-1025) ${ }^{5}$ (Fig.19.3-4).

The finding areas of the pottery and roof covering materials are concentrated in three different areas (Fig.2). The first one among them is an approximately 350-meter-long and 75meter-wide area on the shore of the Hellespont. In this area there are two units, which extend parallel to the coast in north-south direction and remain under water in the periods

- Prof. Dr. Çanakkale Onsekiz Mart University, Faculty of Science and Letters, Derpartment of Art History, ayseturker@comu.edu.tr

A. Ç. Türker, "Hellespont in the Twelfth and Thirteenth Centuries", Proceedings First International Byzantine Studies Symposium, Istanbul 2010a, 312-324; A. Ç. Türker, "Early Christian and Byzantine Archeology on the Valleys around Madytos", Anadolu ve Çeoresinde Ortaçağ 3, 2009, p.51-74; A. Ç. Türker, The Hellespont and the Settlement Patterns in the Byzantine Period: Scamander Valley", Anadolu ve Çeoresinde Ortaçağ 4, 2010, p.53-94; A. C.. Türker, "Lampsacus in Byzantine Period", Bizans ve Cevre Kültürler, Prof. Dr. Yildiz Ötuken'e Ammağgan, İstanbul 2010, p.359-367.

${ }^{2}$ Kepez is a town today which is the $7 \mathrm{~km}$. away from Çanakkale.

${ }^{3}$ Inv. nu.4343, AE 1/2, 24 mm., 4.94 gr., O. Tekin, Yapr Kredi Koleksiyonu Bizans Sikkeleri, İstanbul 1999, nu. 64.

${ }^{4}$ Inv. nu. 4344, AE 1/2, 22 mm., 1.88 gr., P. Grierson, Catalogue of the Byzantine Coins in the Dumbarton Oaks Collection and in the Whittemore Collection, vol. 3, Washington D.C, 1973, nu.7.1.

5 Inv.nu. 4342, AE,32mm., 7.30 gr.; Inv.nu. 2933, AE, 3.35 mm., 15 gr., R. Ratto-Lugano (Suisse), Monnaies Byzantines et d'Autres pays contemporaines a l'époque Byzantine, Amsterdam 1959, nu. 1951. 
when the sea flows, and some architectural ruin consisting of a wall that connects them (Fig.3). One of these units has a circular plan (Fig. 16), while the other one has a rectangular plan (Fig. 14-15). In 1998, a large portion of this area was under soil. Only the unit with a circular plan in the south and some of the wall connecting to it in the north were visible. In this area there were numerous glazed and unglazed wares of Byzantine Period both in the sea and on land. Following the coastal arrangement in 2003 and 2004, destruction occurred in this area. As a result of this destruction, some of the square-planned unit became visible in the north. The architectural ruin herein is $0.40 \mathrm{~m}$ below the surface level in the north and $1.10 \mathrm{~m}$ below the surface level in the south (Fig. 3). In a description in the Searight collection, it is understood that the wall connecting these two units was again in ruins but conserved up to a certain height in the 19th century ${ }^{6}$ (Fig. 17). To understand the type of settlement herein and how far it had spread, we followed the program of the infrastructural activities in Kepez between 1998 and 2002 and drew up the map in Figure 2.

As a result of illegal excavations by treasurers in this area, the wall traces extending vertically to the sea became visible and three in-situ pithoi were destroyed (Fig. 18). The form of the pithoi resembles that of the pithos found again in Kepez and exhibited in Çanakkale Archaeology Museum. The in situ pithoi are buried in the soil between architectural units 1 and 2 in Fig.3. The illegal excavations and the erosion of land by the sea revealed a section showing the stratification in this area. This section was documented by drawing and a layer analysis was made in the place concerned (Fig.4). As a result of the analysis, some four layers displaying a superimposition relation were determined. Layer 1 is the present surface soil. Layer 2 contains mixed materials from the late Byzantine period to the 20th century. Layer 3 is the alluvial layer. Alluvium contains finds of the middle and late Byzantine periods. Finds representing the middle and late Byzantine periods were documented at Layer 4.

The second area (Fig.2.2) is the area used as the Marketplace today, located approximately $300 \mathrm{~m}$ to the east of the coast, as well as its surroundings. During our studies in this area in 2004, the pottery sherds on the surface were documented. After this date, building in Kepez increased rapidly. It is known that Byzantine period wall fragments are encountered from time to time during the foundation excavations for the construction of new buildings. The resemblance of the walls detected in this area and the walls in the 1st area in terms of materials and technique provokes one think that they might have belonged to the same period. The quality of the buildings can only be understood by carrying out systematic excavations. The third finding area (Fig.2.3), where the potteries are concentrated, is the approximately 170-meter-long and 100-meter-wide section between Area 1 and Area 3 that is functioned as a park today. Nevertheless, it is understood that the soil dug during the construction activities in the environment had been dumped into this area and that during landscape design, this soil might have been spread on the surface and used. Thus, the possibility that the finds in this area might have been carried from their original locations and brought to this area should be taken into consideration. 
In areas 1 and 2 in Kepez, we determined a kalypter and five pan tiles belonging to roof covering materials (Fig.5). The roof tiles are unique to the Laconian type ${ }^{7}$. The frame on the long edge has been raised in no. 1 (Fig. 5.1). However, the long edges are smooth in no. 3 and 4 (Fig.5). The parallel of no. 1 is dated to the 10th century in the acropolis of Erythrai ${ }^{8}$. The widths of no. 3 and 4 were measured as 37 and $36 \mathrm{~cm}$, whereas their lengths were measured as 57.5 and $56 \mathrm{~cm}$. The close parallels of these tiles were dated to the late Byzantine Period in Pergamon ${ }^{9}$. Kalypter no. 2 is a specimen that was deformed at the stage of production (Fig. 5, 20). As a result of high heat, sintering occurred on its left long edge. This tile is important as it indicates some production in this area.

The ceramic finds in the locality of Kepez can be evaluated in two main groups, namely unglazed ware and glazed ware. White fabric wares are fewer. This group includes base and body sherds of unglazed kitchen vessels besides glazed bowls (cat. nu. 1-3). Of the unglazed wares, three are base and body sherds of unglazed kitchen vessels. One of the sherds had been made of fabric containing heavy mica (cat. nu. 2) and it has burn marks that were formed during its use. It is reported that cooking pots made of micaceous fabric were considerable in UWW V among the finds of Saraçhane ${ }^{10}$. Because of its resemblance to these wares, the cooking pot in Kepez can be dated to the 12th century. The other fragments have a pinkish fabric color. Pinkish fabric is seen in UWW I among the unglazed finds of Saraçhane ${ }^{11}$.

The white fabric and glazed vessels include bowl and lid sherds (cat. nu. 8-13). The border of a lid (cat. nu. 8) was formed at the wheel and is thin-walled. Its interior is greenglazed, while the exterior is glazed only at the rim. Some 8 specimens of the base sherds of bowls were detected. One of them remained unglazed (cat. nu. 3). It is understood that the interior and the exterior of two bowls including the foot were glazed (cat. nu. 9-10). One of them has colorless glaze, while the interior and the exterior of the second fragment is light green-glazed. Only the interior is glazed in the other specimens. The glaze color is light brown and green (cat. nu. 12-13). These vessels resemble the finds of Sarachane that are dated to the periods of the Macedonians and the Comnenus ${ }^{12}$.

In one of the vessels (cat. nu. 14), brown and green multicolored paint decorations were applied. The glaze on the vessel has considerably shed. A small portion of the decoration has been preserved. According to its parallels, it is dated to the 11 th-12th centuries ${ }^{13}$.

A blackish ink-colored glaze is detected in one of the vessels (cat. nu. 15). It is understood to have had a ring base form; however, the borders of the fragment that was

${ }^{7}$ R. Martin, Manuel D’Architecture Grecque I:Maténaux et techniques, Paris 1965, p. 65, 66, 488.

8 O. Özyiğit, "Alaturka Kiremitin Oluşumu", Arkeolö ve Sanat Tarihi Dergisi V, 1990, p.166, Şek. 7.

${ }^{9} \mathrm{~K}$. Rheidt, Alterümer von Pergamon $\mathrm{XV}_{2}$, Die Statgrbung Teil 2 Die Byzantinische Wohnstadt, BerlinNew York 1991, 30, Abb. 10.

${ }^{10} \mathrm{~J}$. W. Hayes, Excavations at Saraçhane in Istanbul, vol.2, Princeton 1992, 38-39.

"Hayes, ibid, p.38.

12 Hayes, ibid, p.18-21.2

${ }^{13}$ Hayes, ibid, p.29-30. 
found at the seaside and its foot have been extensively abraded. The white fabric is tight and clean. With its fabric and glaze characteristics, it resembles Sarachane GWW III ${ }^{14}$.

The red fabric and unglazed wares include specimens of amphorae and kitchen vessels. The amphorae include mouth, handle and body sherds of Gunsenin types I, III and IV. The most considerable group consists of fragments of amphorae of type IV (cat. nu. 5-6). They are dated to the 12th-13th centuries. Their origin has not been detected yet. Nevertheless, their specimens have been documented in the settlements on the Marmara and Black Sea coasts and in the wreck of Cape Camalti in Turkey, Cherson and Balaklava in Russia, Nesebar in Bulgaria, and Belgrade and Braničevo in Serbia ${ }^{15}$.

Kick-up base sherds of jugs were also documented among the unglazed finds (cat. nu. 4). Those fragments which would enable to understand the mouth and body forms of these jugs could not be detected. However, jugs with a kick-up base form are included in the finds of Perge, Anamur, Saraçhane, Demre and $\mathrm{Chios}^{16}$. Of them, the jugs in Anamur, Saraçhane and Chios are dated to the 7 th century. On the other hand, the jugs in Demre were unearthed at the layers dated to the 9th-10th centuries. The double-handled jugs with an identical base form are also seen among the finds of Tsoukalolagena ${ }^{17}$. It is understood that these vessels not only had been used for wine or water in daily affairs but also had been commercial cargo containers. It is also thought that these jugs were those containers which were used in carrying the oil imported from Italy to Istanbul and Pontus by the Genoese merchants in the 14th century ${ }^{18}$. The facts that the kick-up bases in the locality of Kepez are surface finds and that those fragments which will enable us to understand the body forms are missing make it difficult to perform a final dating. Nevertheless, according to the parallels, it can be stated that they might have belonged to the middle or late Byzantine period.

There is a massive horizontal handle fragment among the unglazed wares. It must have belonged to the body of a closed vessel (cat. nu. 7). An incised decoration of wavy lines and spirals are seen on it. The second specimen of the unglazed vessels with an incised decoration is the body sherd of a jug. Vessels with a similar incised decoration were unearthed in Ephesus, Thesssaloniki and Nichoria in Greece and in settlements on Keos ${ }^{19}$ and they are dated to the 11 th-12th centuries. The finds of Kepez can also be dated to the same period.

${ }^{14}$ Hayes, ibid, p.29-30.

15 N.Günsenin, "Recherches sur les amphores Byzantines dans les musées turcs", V. Déroche- J.-M. Spieser (ed.), Recherches sur la Céramique Byzantine BCH Suppl. XVIII, 1989, p.276, Z. Brusic, "Late Antique and Byzantine Underwater Finds along the Eastern Coast of the Adriatic", Balslav 5, 1976, 44, pl.VII, fig.8; J. Cangova, "Amphores du Moyen Age en Bulgarie" Sofia 22, 1959, p.258, fig. 13, A. Ç. Türker, Byzantine Unglazed Pottery of Saint Nicholas Church at Demre-Myra, İstanbul 2009b, p.98, nu.176.

16 N. Atik, Die Keramik aus den Südthermen von Perge, Tübingen 1995, 197, fig.86.464; C. Williams, Anemurium the Roman and Early Byzantine Pottery, Toronto 1989, fig.52.525; J. W. Hayes, "Excavations at Saraçhane in Istanbul”, DOP 22,1968, p.204-7,fig.26; Türker 2009b, 77-79; M.Ballance-J.Boardman-S.Corbett-S.Hood, Excavations in Chios 1952-1955 Byzantine Empono, Oxford 1989, p.102, fig.33.199-201

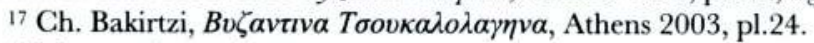

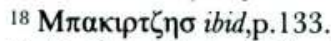

19 D. Papanikola-Bakirtzi (ed.), Everyday life in Byzantium, Athens 2002, 356, nu.416; J. Vroom, Byzantine to Modern Pottery in the Aegean, Bijlefeld 2005, p.70-71. 
The red fabric and glazed wares include specimens of sgraffito, plain glazed, Aegean, champleve and Zeuxippus ware. There are mouth and body sherds of plates and jugs in the sgraffito ware. The incised parts forming the decorations are quite deep (cat. nu. 4-21). Probably the body of a bird figure and some of its foot are observed on two body sherds (cat. nu. 16-17). Their bodies were filled with parallel lines. Parallels are included in the late Byzantine pottery in Thrace ${ }^{20}$. They are closely and regularly situated lines in a specific order. Incrustation motifs of similar type are detected on the bodies of the bird and human figures on the polychrome sgraffiti on Cyprus ${ }^{21}$. The glazed finds include a mouth and a body sherd of the jugs, of which we have few specimens (cat. nu. 20). Depending on the decoration technique, these two sherds of the same vessel belong to the second half of the 12th century-the 13th century. The Aegean ware ${ }^{22}$ (cat. nu. 22-24) that is dated to the same period is represented with three specimens, while the champleve ware (cat. nu. 25) is represented with one specimen.

In plain glazed ware (cat. nu. 26-31), the bases are generally of a low ring base type. There are one sherd with a flat base form (cat. nu. 31). The interior surfaces are glazed, whereas only the area until the lower section of the mouth is glazed on the exterior. The glaze is light yellow or light green. Dark green glaze is observed on few sherds. Tripod marks can be detected on the interior of the bowls. These wares belong to the late 12 th century-the 13 th century.

The fabric of the ware in Zeuxippus I is tight (cat. nu. 32-42). Incised decorations produced by means of a tool with a fluted tip are observed on the interior of the bowls. The decoration generally consists of concentric circles. The incised parts are as deep as to incise the slip. The glaze is brilliant and was applied as a thick layer. The sherds are generally bases of bowls. Two types of base form are detected. One of them is a high base that opens like a bell, while the other one is a low ring base. In the specimens of the first group, the glaze is light green or colorless. In the second group, yellow orange and yellowish brown glaze is seen. The decorations generally consist of concentric circles and a row of spirals with an open end. Wares with a plant decoration at the rim were also documented. One of them (cat. nu. 42) has a broad band with rinceau motif. A similar decoration composition can be detected on a handle sherd in the Benaki Collection. This sherd is defined as a characteristic example of the Seres workshops ${ }^{23}$.

The decoration compositions in the Zeuxippus ware II (cat. nu. 43-48) consist of concentric circles in the middle of the interior of bowls and plates or a chevron or simple plant decorations placed inside lockets. The decorations at the rim are generally lines or spirals with an open end situated in a narrow band. The glaze applied on the slip is brilliant and was applied as a thick layer. Colorless or light green glaze was used on the bowls and

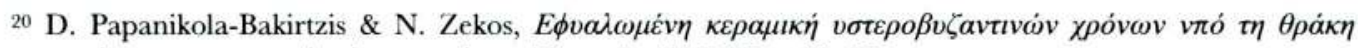

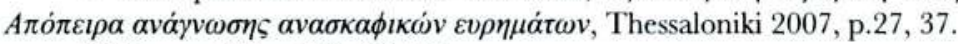

21 Vroom, ibid, p.120, 7.2, 7.4.

${ }^{22}$ A. H. S. Megaw, "An Early Thirteenth Century Aegean Glazed Ware”, G. Robertson \& G. Henderson (eds.) Studies in Memory of D. T. Rice, Edinburgh, 1975, p.34-45, pls.14-17.

${ }^{23}$ D. Papanikola-Bakirtzi \& F. N. Mavrikioy \& Ch. Bakirtzis, Byzantine Glazed Pottery in the Benaki Museum, Athens 1999, nu.333. 
plates. There are two body sherds of jugs in this group (cat. nu. 44-47). They are distinguished from the characteristic examples of Zeuxippus ware II by their glaze color. On one of the body sherds is a combed decoration seen widely in the Zeuxippus ware (cat. nu. 43-44). The decoration was enriched with brown paint. Nevertheless, the surface was covered with dark green glaze instead of transparent or light yellow glaze ${ }^{24}$. The finds of Chrysopolitissa include a fragment, on which green glaze was used ${ }^{25}$. Bakirtzis shows this fragment as an example and states that subgroups are also needed for ZW II. There is a decoration of spirals with an open end on the second body sherd of a jug (cat. nu. 47). The decoration enriched with brown paint was orange-glazed. Wares in the Zeuxippus were detected in three more areas on the Kalabaklı Valley during our studies. Moreover, during our studies in the Hellespont, numerous fragments were documented also in Lampsacus, Pegai, Madytos ${ }^{26}$, Eski Hisarlık (Eleius), Karaağactepe, Sestos, Kallipolis and Kokarpınar. The ceramic finds in Gülpınar and Troy include specimens of Zeuxippus ware ${ }^{27}$.

The ceramic finds we documented in the localities of Kepez at the mouth of the Kalabaklı Valley indicate the middle and late Byzantine period. There are also specimens that were left unslipped and unglazed and that might be accepted as data of the ceramic production in the region. The unglazed specimens include white-fabric vessels. Moreover, defectively-fired items are determined among the terra cotta roof covering materials as well (Fig. 5.2). In addition, a tripod among the finds is an essential data that might indicate some production herein ${ }^{28}$ (Fig.24.48). The use of tripods in the Byzantine ceramic production coincides with circa $1200^{29}$. The Zeuxippus ware that might be dated to this period is the most considerable ware in the settlements both on the Kalabakh Valley and on the coast of the Hellespont. Researchers also indicate that the production center(s) of this ware, the production centers outside Istanbul of which have not been determined yet, might be located in an area close to the Hellespont ${ }^{30}$.

The hill in the southwest of the Kalabakl Tributary, which is the southern border of the Sarısığlar Bay in about $1.5 \mathrm{~km}$ to the southwest of Kepez, and the western and southwestern

${ }^{24}$ Jugs with an identical decoration but covered with colorless glaze are also included in the finds of Chersonesos, Kavala and the Castle of Torone, Papanikola-Bakirtzi \& Zekos, ibid, p.44, 73. P. Armstrong, "The Earlier Byzantine Castle at Torone", The Australian Archaeological Institute at Athens Bulletin, 3, 2005, fig.7.

25 D. Papanikola-Bakirtzis, "Zeuxippus Ware: Some Minor Observations", Mosaic Festschrift for A. H. S. Megaw, London 2001, p.132.

26 A. Ç. Türker, "Glazed Byzantine Pottery in Eceabat-Madytos" XII.Ortą̧ağ-Türk Dönemi Kazllan ve Sanat Tarihi Sempozyumu Bildinilen, İzmir 2009c, p.15-29.

${ }^{27}$ F. Yenişehirlioğlu, "La céramique glaçurée de Gülpınar", V. Déroche-J.-M. Spieser (ed.), Recherches sur la Céramique Byzantine BCH Suppl. XVIII, 1989, p.303-315; F. Yenişehirlioğlu, "Apollo Smintheus Tapınağında Sırlı Ortaçağ Anadolu Seramiği", Araştınna Sonu̧̧lan Toplantıst I, Ankara 1983, p.175-181. J. W. Hayes, "A Late Byzantine and Early Ottoman Assemblage from the Lower City in Troia", Studia Troica 5, 1995, p.197-210.

${ }^{28}$ A tripod of identical type was determined in Didymoteichon, D. Papanikola-Bakirtzis, "The Tirpod Stilts of Byzantine and Post-Byzantine Pottery" (in Greek), Amētos, Volume in Honor of Professor Manolis Andronikos, Thessaloniki 1986, p.641-48, N.130.

29 D. Papanikola-Bakirtzis, "Serres: A Glazed-Pottery production Center During The Late Byzantine Period”, Ch. Bakirtzis and S. Wissemann (eds.) Ceramic Art From Byzantine Serres, Ilionis Byzantine Studies III, USA 1992, p.26.

${ }^{30}$ N. Zekos, Maximianoupolis-Mosynopolis, The Excavation of a Central Plain Church, Kavala 2008. 
slopes of the hill are known as the locality of Dardanos (Fig. 1). The ancient city of Dardanos is also localized in this area $^{31}$.

The locality of Dardanos consists of the hill, where Hasan Mevsuf Cemetery of Martyrs in the southwest of the Kalabaklı Tributary - the southern border of the Sarısıglar Cove - is located, and the western and southwestern slopes of the hill. It is considered that the city of Dardanos had been located at Cape Kepez on the southern border of the Sansiglar Cove and that the acropolis of the settlement had been located on the plain hill ${ }^{32}$. The fact that its settlement had extended from the southwestern ridges of the Hill towards the shore of the strait was detected by the unglazed ware. Finds of the Byzantine period are not mentioned in these studies. However in written sources, one of the episcopacies in the Hellespontus region is recorded as Dardanos ${ }^{33}$. Dardanos, as an episcopacy center affiliated to the metropolitanate of Kyzikos, was mentioned in all notitiae from the midst of the 5th century to the 13th century ${ }^{34}$. The first evaluations of the wares indicate that the settlement of the episcopacy of Dardanos had spread on both sides of the mouth of the Kalabakl Tributary. Moreover, with the dating of the wares, it is understood that the settlement in this area had been uninterruptedly settled from the early Byzantine period to the late Byzantine period. This finding is also supported by the episcopal lists and the seals of the bishops of Dardanos.

31 W. Leaf, Strabo on Troad, Cambridge 1923, 28; J. M. Cook, The Troad, Oxford 1973, p.58.

32 Leaf and Cook think that Akyarlar constituted the southern border of the territory of Dardanos. Leaf states that no traces of buildings are seen on the hill but the land is full of pottery sherds (Leaf, ibid. p.28). He states that there was a castle called the Castle of Dardanos on the western ridge of the hill. Cook states that there is a very steep ridge separating the land of the settlement on the hill from the land at the seaside and that this might be considered as the defense line of the castle, Cook, ibid, p.58. The wall, which might have belonged to the castle that the researchers state, is not found today; however, mortared wall fragments with a thickness of approximately $1.75 \mathrm{~cm}$. extending towards the strait in north-south direction at the northern corner of the hill were documented during our studies. The visible wall technique here indicates the late Ottoman period. According to these data, for the time being, it might be stated that this wall had belonged to the battery in World War I.

33 The name of the episcopacy is mentioned as Dardanon in the lists and on the seals of the Byzantine period, J. Darrouzés, Notitiae Episcopatuum Ecclesiae Constantinopolitanae. Paris 1981, p.207, 220, 234, 253, 276, 297, 312, 355; J. W. Nesbit \& J. Oikonomides, Byzantine seals at Dumbarton Oaks and in the Fogg Museum of Art, vol. 3, Washington D.C. 1996, 91. In the sources on the history of church, it was recorded as Dardanus or Dardanum. M. L'abbe Fleury, The Ecclesiastical History A.D.410-429, Oxford 1843, 201; R. Price \& M. Gaddis, The Acts of the Council of Chalcedon, vol 1, Liverpool 2005, p.8,79, 40, 95, 108, 123, 127, 237, 298; J.Christal, The Authoritative Christianity vol 3, The First Ecumenical Council Which was Held A.D. at Nicaea in Bithynia, New Jersey 2010, p.71.

34 In a record of 410 , the name of the bishop of Dardanos was mentioned as Dioscorus. Nesbit \& Oikonomides, ibid., 91-92; Bishop Petrus attended the Council of Kadıköy (M. L'abbe Fleury, The Ecclesiastical History A.D.410-429, Oxford 1843, 201; R. Price \& M. Gaddis, The Acts of the Council of Chalcedon, vol 1, Liverpool 2005, p.8, 40, 79, 95, 108, 123, 127, 237, 298), while bishop Strategius attended the Second Council of İznik. In the sources, it is mentioned that Strategios had clearly expressed his opinions against iconoclasts during the council. It is thought that his name was therefore added to the list of the $2^{\text {nd }}$ session only although probably he had attended all sessions. This is expressed as a formula that was found by Pope Hadrian I. It is suggested that Strategios, the bishop of Dardanos, approved of giving support for showing respect to the icons at the $4^{\text {th }}$ session and that his name was added to the list thereafter (F. Winkellmans, R.- J. Lilie, C. Ludwig, T. Pratsch, I. Rochow, B. Zielke, Prosopographie der mittelbyzantinischen Zeit, Berlin 2002, p.7132). For the seal of Soterichos, the bishop of Dardanos in the $11^{\text {th }}$ and $12^{\text {th }}$ centuries, Nesbitt \& Oikonomides, ibid. nu.44.1. 


\section{Catologue :}

1. Jar, Location:Area 1, UTM ${ }^{35}$ 35T 448717.07 E 4439691.60 N elev. 2m.; base sherd, d:0.085, porous fabric $(10 \mathrm{R} 8 / 2)^{36}$ contains medium lime, coarse grit, chamotte.

2. Jar, Location: Area 1, UTM 35T 448717.07 E $4439691.60 \mathrm{~N}$ elev. 2m., base sherd, d:0.10, porous fabric (2.5YR8/2) contains sparse mica, medium coarse grit, chamotte.

3. Bowl, Location: Area 1, UTM 35T 448712.01 E $4439667.94 \mathrm{~N}$ elev. 2m., base sherd, d:0.05, hardly fired fabric $(2.5 \mathrm{Y} 8.5 / 2)$ contains sparse fine sand, plant-temper.

4. Jug, Location: Area 1, UTM 35T 448717.07 E 4439691.60 N elev. 2m., kick-up base sherd, d:0.064, hardly fired fabric (5YR9/2) contains sparse fine sand, plant-temper.

5. Amphora, Location: Area 3, UTM 35T 448865.71 E $4439650.08 \mathrm{~N}$ elev. 8m., rim and handle sherd, d:0.06, hardly fired fabric $(5 \mathrm{YR} 6 / 10)$ contains heavy grit, chamotte and mica.

6. Amphora, Location: Area 1, UTM 35T 448717.07 E $4439691.60 \mathrm{~N}$ elev. 2m., rim and handle sherd, d:0.05, hardly fired fabric $(2.5 \mathrm{YR} 6 / 10)$ contains heavy fine mica, grit.

7. Handle, Location: Area 2, UTM 35T 448769.76 E 4439721.99 N elev. 5m., soft, porous fabric $(10 \mathrm{R} 6 / 12)$ contains medium fine lime, incised decoration of wavy lines and spirals.

8. Lid, Location: Area 2, UTM 35T 448788.58 E 4439686.85 N elev. 6m., wall sherd, est.d:0.16, hardly fired fabric $(5 \mathrm{Y} 8.5 / 2)$ contains medium fine mica, sand, plant-temper, upper surface and rim are green-glazed (5GY5/4), slip is present between the glaze and the fabric.

9. Bowl, Location: Area 2, UTM 35T 448794.37 E 4439699.23 N elev. 6m., base sherd, d:0.04, hardly fired fabric (5YR9/2) contains medium coarse chamotte, fine grit, light green $(7.5 \mathrm{Y} 8.5 / 4)$ glaze was applied on a thin layer of slip. The glaze covers the whole interior and exterior surfaces including the lower section of the base. A tripod mark is present on the exterior.

10. Bowl, Location: Area 1, UTM 35T 448712.01 E $4439667.94 \mathrm{~N}$ elev. 2m., base sherd, d:0.036, hardly fired fabric (10YR9/2) contains sparse fine sand, pale green glaze (7.5Y8.5/2) applied on the slip covers the whole interior and exterior surfaces including the lower section of the base.

11. Jug, Location: Area 1, Area 2, TM 35T 448739.40 E 4439713.47 N elev. 3m., base sherd, d:0.05, hardly fired fabric (10YR8/2) contains heavy fine grit, light green $(7.5 \mathrm{Y} 8.5 / 4)$ glaze applied directly on the fabric as a thin layer on the interior.

12. Jug, Location: Area 2, UTM 35T 448740.14 E 4439665.45 N elev. 3m., base sherd, d:0.05, hardly fired fabric (10YR9/2) sparse fine sand, medium plant-temper, a thin layer of

${ }^{35}$ Universal Transverse Mercator.

36 The Munsell Book of Color. 
slip, the interior is green-glazed $(5 \mathrm{GY} 6 / 6)$, the glaze was applied as a thin layer; it is not spread equally on the surface; and it is in the form of waves in light and dark shades.

13. Bowl, Location: Area 2, UTM 35T 448762.32 E 4439641.25 N elev. 5m., base sherd, d:0.06, from its foot section, it is understood to have been a flawed production, some portion of the ring base is slightly crushed. moderately fired porous fabric (7.5YR9/2), sparse medium chamotte, grit, plant temper, the glaze $(2.5 \mathrm{Y} 6 / 8)$ applied directly on the fabric is observed on the interior only.

14. Jug, Location: Area 1, UTM 35T 448717.72 E 4439685.93 N elev. 2m., base sherd, d:0.062, moderately fired soft fabric $(2.5 \mathrm{YR} 8 / 2)$ contains sparse medium grit, plant-temper, chamotte, multicolored painting with only a small preserved portion on the interior, no slip.

15. Dish, Location: Area 1, UTM 35T 448717.72 E 4439685.93 N elev. 2m., base sherd, d:0.09, hardly fired fabric $(2.5 \mathrm{YR} 9 / 2)$ contains sparse fine grit, chamotte, the glaze that was applied directly on the fabric has a blackish ink color (10R9/2).

16. Dish, Location: Area 2, UTM 35T 448767.36 E 4439690.58 N elev. 4m., wall sherd, hardly fired fabric $(7.5 \mathrm{YR} 6 / 6)$ contains sparse medium mica, grit, lime, plant-temper, some portions of the foot and body of a bird figure are observed on the interior, the body is filled with parallel lines, light green glaze $(5 \mathrm{Y} 8 / 6)$ on the interior.

17. Dish, Location: Area 2, UTM 35T 448747.51 E 4439684.17 N elev. 5m., wall sherd, hardly fired fabric $(7.5 \mathrm{YR} 6 / 6)$ contains sparse medium mica, grit, lime, plant-temper, some portions of the body of a figure are observed on the interior, the body is filled with parallel lines, light green glaze (5Y8/6) on the interior.

18. Dish, Location: Area 3, UTM 35T 448889.91 E $4439754.53 \mathrm{~N}$ elev. 8m., rim sherd, hardly fired fabric $(7.5 \mathrm{YR} 6 / 6)$ contains sparse medium mica, grit, light green glaze $(5 \mathrm{Y} 8 / 6)$ on the interior.

19. Dish, Location: Area 1, UTM 35T 448712.01 E $4439667.94 \mathrm{~N}$ elev. 2m., wall sherd, hardly fired fabric (5YR5/8) heavy fine mica, lime, grit, cream slip on the interior, green glaze $(5 \mathrm{Y} 7 / 8)$ has been considerably shed, plant motifs understood to have been situated in a band in the upper section of the body.

20. Jug, Location: Area 2, UTM 35T 448785.34 E $4439720.71 \mathrm{~N}$ elev. 5m., rim and wall sherd, d:0.08, hardly fired fabric (5YR6/8) sparse fine lime, grit, glaze $(7.5 \mathrm{Y} 8.5 / 6)$ on the cream slip was applied as a thin layer, a decoration of incised lines on the neck, on the body are intersecting lines to form equilateral quadrangles and "V" shaped lines situated in them as well as concentric circles.

21. Dish, Location: Area 2, UTM 35T 448794.37 E 4439699.23 N elev. 6m., rim sherd, d:0.18, hardly fired fabric $(2.5 \mathrm{YR} 5 / 8)$ sparse fine sand, grit, glaze $(2.5 \mathrm{Y} 7 / 10)$ on the interior and at the rim on the exterior, three lines situated in parallel to each other at the rim and a spiral extending downwards in its lower section.

22. Bowl, Location: Area 2, UTM 35T 448860.14 E $4439644.65 \mathrm{~N}$ elev. 8m., rim sherd, d:0.20, moderately fired porous fabric (7.5YR6/4) contains medium lime, grit, cream 
slip on the interior and in the lower section of the mouth on the exterior. Lemon yellow glaze $(2.5 \mathrm{Y} 8 / 6)$. Only the interior and rim are glazed.

23. Bowl, Location: Area 2, UTM 35T 448794.76 E $4439710.57 \mathrm{~N}$ elev. 6m., rim sherd, est.d:0.24, moderately fired porous fabric (5YR5/6) heavy coarse grit, lime, green $(2.5 \mathrm{GY} 7 / 6)$ glaze on the interior and exterior, but the glaze was applied on the fabric without any slip on the exterior and, therefore, it has a darker color.

24. Bowl, Location: Area 1, UTM 35T 448717.72 E 4439685.93 N elev. 2m., rim sherd, est.d:0.22, hardly fired fabric (5YR6/10) contains medium fine grit, lime, light green $(7.5 \mathrm{Y} 8 / 6)$ glaze on the interior and in the lower section of the mouth on the exterior.

25. Dish, Location: Area 2, UTM 35T 448764.41 E 4439675.27 N elev. 5m., base sherd, d:0.12, hardly fired fabric (5YR6/6) contains heavy medium lime, mica, cream slip on interior, interior shiny dark and green glaze $(2.5 \mathrm{Y} 7 / 8)$, exterior washed with cream glaze $(2.5 Y 8.5 / 2)$.

26. Dish, Location: Area 1, UTM 35T 448717.07 E $4439691.60 \mathrm{~N}$ elev. 2m., base sherd, d:0.06, hardly fired fabric $(7.5 \mathrm{YR} 5 / 8)$ contains medium fine lime, grit, on interior gren glaze $(7.5 \mathrm{Y} 8 / 12)$ on exterior upper part of the body gren glaze and incised line, in wall one repair hole.

27. Dish, Location: Area 1, UTM 35T 448730.40 E $4439700.65 \mathrm{~N}$ elev. 2m., base sherd, d:0.058, hardly fired fabric $(5 \mathrm{YR} 6 / 10)$ contains sparse fine lime, mica, cream slip on interior, colourless glaze.

28. Dish, Location: Area 1, UTM 35T 448717.07 E $4439691.60 \mathrm{~N}$ elev. 2m., base sherd, d:0.048, moderately fired, porous, soft fabric $(7.5 \mathrm{YR} 6 / 8)$ contains medium coarse lime, grit, green glaze $(5 \mathrm{Y} 8 / 6)$ on interior, tripot stilt is seen on exterior

29. Dish, Location: Area 1, UTM 35T 448730.40 E 4439700.65 N elev. 2m., base sherd, d:0.10, hardly fired fabric (5YR6/8) contains medium fine lime, grit, pale green glaze $(2.5 \mathrm{GY} 7 / 10)$ on interior tripot stilt is seen on glaze.

30. Dish, Location: Area 1, UTM 35T 448730.40 E $4439700.65 \mathrm{~N}$ elev. 2m., base sherd, d:0.06, hardly fired fabric $(5 \mathrm{YR} 7 / 6)$ contains heavy fine lime, mica, grit, pale green $(7.5 \mathrm{Y} 8.5 / 2)$ glaze on interior.

31. Jug, Location: Area 1, UTM 35T 448730.40 E 4439700.65 N elev. 2m., base sherd, $\mathrm{d}: 0.07$, hardly fired fabric $(2.5 \mathrm{YR} 6 / 6)$ contains sparse fine lime, grit, mica, cream slip traces and dark green glaze (10YR4/6) on interior.

32. Bowl, Location: Area 1, UTM 35T 448717.07 E 4439685.93 N elev. 2m., complete profile, d:rim:0.13, base:0.5 ht:0.065, hardly fired fabric (5YR5/8) contains heavy fine mica, grit, the interior surface and the section of the exterior surface until the lower section of the body are white-slipped, a decoration of concentric circles and light yellow glaze (7.5Y8.5/6) on the interior. 
33. Dish, Location: Area 2, UTM 35T 448758.56 E $4439714.55 \mathrm{~N}$ elev. 4m., base sherd, d:0.068, hardly fired fabric $(7.5 \mathrm{YR} 6 / 8)$ contains heavy fine mica, sand, cream slip and pale yellow glaze on interior, chevron in central medallion, two concentric circles on centre; back of base " $\mathrm{X}$ " shaped grafiti.

34. Dish, Location: Area 1, UTM 35T 448712.01 E $4439667.94 \mathrm{~N}$ elev. 2m., base sherd, d:0.049, hardly fired fabric $(2.5 \mathrm{YR} 6 / 4)$ contains heavy fine mica, sand, lime, pale yellow glaze $(2.5 \mathrm{Y} 7 / 10)$ on interior, tree concentric circles on centre.

35. Dish, Location: Area 1, UTM 35T 448717.72 E $4439685.93 \mathrm{~N}$ elev. 2m., base sherd, d:0.058, hardly fired fabric (5YR6/8) contains heavy fine mica, cream slip on interior and exterior, pale green glaze $(7.5 \mathrm{Y} 8 / 6)$, tree concentric circles on centre.

36. Bowl, Location: Area 3, UTM 35T 448860.14 E $4439644.65 \mathrm{~N}$ elev. 8m., base sherd, d:0.07, hardly fired fabric $(5 \mathrm{YR} 6 / 10)$ contains medium fine grit, mica, pale green glaze $(7.5 \mathrm{Y} 8 / 6)$ on interior, two concentric circles on centre.

37. Dish, Location: Area 2, UTM 35T 448785.34 E 4439720.71 N elev. 5m., base sherd, d:0.052, hardly fired fabric (5YR6/8) contains medium fine lime, grit, plant-temper, pale green glaze $(10 \mathrm{Y} 8 / 4)$ on interior, one concentric circles on centre.

38. Dish, Location: Area 1, UTM 35T 448730.40 E 4439700.65 N elev. 2m., base sherd, d:0.054, hardly fired fabric $(5 \mathrm{YR} 6 / 8)$ contains heavy fine grit, lime, medium mica, pale green glaze $(10 \mathrm{Y} 8 / 6)$ on interior, four concentric circles on centre.

39. Dish, Location: Area 1, UTM 35T 448739.40 E 443713.47 N elev. 3m., base sherd, d:0.08, hardly fired fabric $(2.5$ YR6/8) contains medium fine lime, grit, cream slip on interior, orange-brown glaze (7.5YR5/10), two concentric circles on centre, back of base "K" shaped grafiti,

40. Dish, Location: Area 2, UTM 35T 448794.76 E $4439710.57 \mathrm{~N}$ elev. 6m., base sherd, d:0.06, hardly fired fabric $(7.5 \mathrm{YR} 6 / 10)$ contains medium fine mica, grit, plant-temper, orange-brown glaze (10YR7/8) on interior, tripot stilt is seen on glaze.

41. Dish, Location: UTM 35T 448758.56 E $4439714.55 \mathrm{~N}$ elev. 4m., base sherd, d:0.07, hardly fired fabric $(5 \mathrm{YR} 5 / 10)$ contains heavy fine mica, crem slip on interior and gren $(5 \mathrm{Y} 7 / 10)$ glaze.

42. Bowl, Location: Area 2, UTM 35T 448785.34 E 4439720.71 N elev. 5m., rim sherd, est.d:0.16, hardly fired fabric $(5 \mathrm{YR} 6 / 10)$ contains medium fine grit, orange-brown glaze (10YR6/12) on interior and exterior, a broad band with rinceau motif

43. Dish, Location: Area 3, UTM 35T 448865.34 E 4439643.23 N elev. 8m., base sherd, d:0.08, moderately fired fabric (5YR6/6) contains heavy fine grit, lime, plant-temper, cream slip on interior and colorless glaze at the rim on the exterior, brown painting beneath the glaze, three concentric circles at the center, combed decorations repeated at certain intervals on the body and vertically incised lines between them. 
44. Jug, Location: Area 2, UTM 35T 448758.56 E 4439714.55 N elev. 4m., wall sherd, hardly fired fabric $(5 \mathrm{YR} 6 / 10)$ grit, lime, mica, dark green glaze $(2.5 \mathrm{GY} 5 / 6)$ on exterior, brown painting beneath the glaze. Lines formed with a comb in the visible section of the decoration and incised lines forming spirals between them.

45. Jug, Location: Area 1, UTM 35T 448712.01 E 4439667.94 N elev. 2m., base sherd, $\mathrm{d}: 0.08$, moderately fired soft fabric $(7.5 \mathrm{YR} 6 / 6)$ contains sparse fine mica, grit, plant-temper, colorless glaze on the exterior, brown painting beneath the glaze, two wavy lines horizontally encircling the lower section of the body.

46. Dish, Location: Area 3, UTM 35T 448854.85 E 4439640.12 N elev. 8m., rim sherd, d:0.27, hardly fired fabric (5YR6/8) contains sparse fine lime, grit, linear decorations inside the border formed with incised lines at the rim, the decoration is enlivened with brown paint. light green glaze $(5 \mathrm{Y} 8 / 6)$ on the interior and only at the rim on the exterior.

47. Jug, Location: Area 2, UTM 35T 448740.14 E 4439665.45 N elev. 3m., wall sherd, hardly fired fabric (2.5YR6/6), sparse fine mica, grit, lime, cream slip on the exterior, the decoration in fine sgraffito technique consists of spirals with an open end, lines and concentric circles, orange-brown glaze $(2.5 \mathrm{Y} 6 / 8)$ on the exterior.

48. Dish, Location: Area 1, UTM 35T 448717.07 E $4439691.60 \mathrm{~N}$ elev. 2m., base sherd, d:0.08, hardly fired fabric (5YR5/8) contains medium fine mica, light green (5Y8.5/6) glaze applied to form a thick surface on a thick layer of cream slip, light brown painting beneath the glaze, an incised decoration likely to have belonged to the body of an animal figure. 


\section{REFERENCES}

Atik, N., Die Keramik aus den Südthermen von Perge, Tübingen 1995.

Armstrong, P., "The Earlier Byzantine Castle at Torone", The Australian Archaeological Institute at Athens Bulletin, 3, 2005 , 9-15.

Ballance, M.- J. Boardman - S. Corbett - S. Hood, Excavations in Chios 1952-1955 Byzantine Emporio, Oxford 1989.

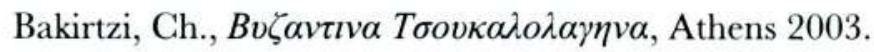

Brusic, Z., "Late Antique and Byzantine Underwater Finds along the Eastern Coast of the Adriatic", Balslav 5, 1976, 31-39.

Cangova, J. "Amphores du Moyen Age en Bulgarie” Sofia 22, 1959, 243-62.

Christal, J., The Authoritative Christianity vol 3, The First Ecumenical Council Which was Held A.D. at Nicaea in Bithynia, New Jersey 2010.

Cook, J. M., The Troad, Oxford 1973.

Darrouzés, J., Notitiae Episcopatuum Ecclesiae Constantinopolitanae. Paris 1981.

Grierson, P., Catalogue of the Byzantine Coins in the Dumbarton Oaks Collection and in the Whittemore Collection, vol. 3, Washington D.C, 1973.

Günsenin, N., "Recherches sur les amphores Byzantines dans les musées turcs", V. Déroche-Spieser, J.-M. (ed.), Recherches sur la Céramique Byzantine BCH Suppl. XVIII, 1989, 267-276.

Hayes, J. W., "Excavations at Saraçhane in Istanbul”, DOP 22,1968, 195-216.

Hayes, J. W., Excavations at Saraçhane in Istanbul, vol.2, Princeton 1992.

Hayes, J. W., "A Late Byzantine and Early Ottoman Assemblage from the Lower City in Troia", Studia Troica 5, 1995, 197-210.

L'abbe Fleury, M., The Ecclesiastical History A.D.410-429, Oxford 1843.

Leaf, W., Strabo on Troad, Cambridge 1923.

Martin, R., Manuel d'Architecture Grecque 1:Matériaux et techniques, Paris 1965, 65, 66, 488.

Megaw, A. H. S., "An Early Thirteenth Century Aegean Glazed Ware”, G. Robertson \& G. Henderson (eds.): Studies in Memory of D. T. Rice, Edinburgh, 1975, 34-45

Nesbit, J. W. \& J. Oikonomides, Byzantine seals at Dumbarton Oaks and in the Fogg Museum of Art, vol. 3, Washington D.C. 1996.

Özyiğit, Ö., “Alaturka Kiremitin Oluşumu”, Arkeolö̈ ve Sanat Tarihi Dergisi V, 1990, 149-179.

Papanikola-Bakirtzi, D. "The Tirpod Stilts of Byzantine and Post-Byzantine Pottery" (in Greek), Amētos, Volume in Honor of Professor Manolis Andronikos, Thessaloniki 1986, 641-48.

Papanikola-Bakirtzi, D. \& F. N. Mavrikioy \& Ch. Bakirtzis, Byzantine Glazed Pottery in the Benaki Museum, Athens 1999.

Papanikola-Bakirtzi, D., "Zeuxippus Ware: Some Minor Observations", Mosaic Festschrift for A. H. S. Megaw, London 2001, 131-134. 
Papanikola-Bakirtzi, D. (ed.), Everyday life in Byzantium, Athens 2002.

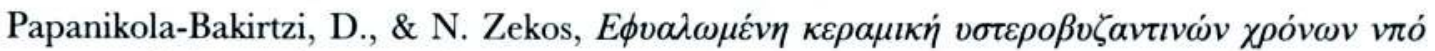

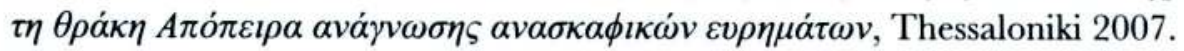

Price, R. \& M. Gaddis, The Acts of the Council of Chalcedon, vol 1, Liverpool 2005.

Ratto-Lugano, R. (Suisse), Monnaies Byzantines et d'Autres pays contemporaines a l'époque Byzantine, Amsterdam 1959

Rheidt, K., Alterümer von Pergamon $\mathrm{XV}_{2}$, Die Statgrabung Teil 2 Die Byzantinische Wohnstadt, BerlinNew York 1991.

Tekin, O., Yapr Kredi Koleksiyonu Bizans Sikkeleri, İstanbul 1999.

Türker, A. Ç., "Early Christian and Byzantine Archeology on the Valleys around Madytos", Anadolu ve Çevresinde Ortaçag 3, 2009a, 51-74.

Türker, A. Ç., Byzantine Unglazed Pottery of Saint Nicholas Church at Demre-Myra, İstanbul 2009b.

Türker, A. Ç., "Hellespont in the Twelfth and Thirteenth Centuries", Proceedings First International Byzantine Studies Symposium, Istanbul 2010a, 312-324.

Türker, A. Ç., The Hellespont and the Settlement Patterns in the Byzantine Period: Scamander Valley", Anadolu ve Çevresinde Ortaçag 4, 2010b, 53-94.

Türker, A. Ç., "Lampsacus in Byzantine Period", Bizans ve Çevre Kültürleri, Prof. Dr. Mildiz Otuken'e Armagan, Istanbul 2010c, 359-367.

Türker, A. Ç., "Glazed Byzantine Pottery in Eceabat-Madytos” XII.Ortaçağ-Türk Dönemi Kazilan ve Sanat Tarihi Sempozyumu Bildirileri, İzmir 2009c,15-29.

Vroom, J., Byzantine to Modern Pottery in the Aegean, Bijlefeld 2005.

Williams, C., Anemurium the Roman and Early Byzantine Pottery, Toronto 1989.

Winkellmans, F. R.- J. Lilie, C. Ludwig, T. Pratsch, I. Rochow, B. Zielke, Prosopographie der mittelbyzantinischen Zeit, Berlin 2002.

Yenişehirlioğlu, F., “Apollo Smintheus Tapınağında Sırlı Ortaçağ Anadolu Seramiği”, Araştırma Sonu̧lan Toplantısı I, Ankara 1983, 175-181.

Yenişehirlioğlu, F., "La céramique glaçurée de Gülpınar", V. Déroche-J.-M. Spieser (ed.), Recherches sur la Céramique Byzantine BCH Suppl. XVIII, 1989, 303-315.

Zekos, N., Maximianoupolis-Mosynopolis, The Excavation of a Central Plain Church, Kavala 2008. 


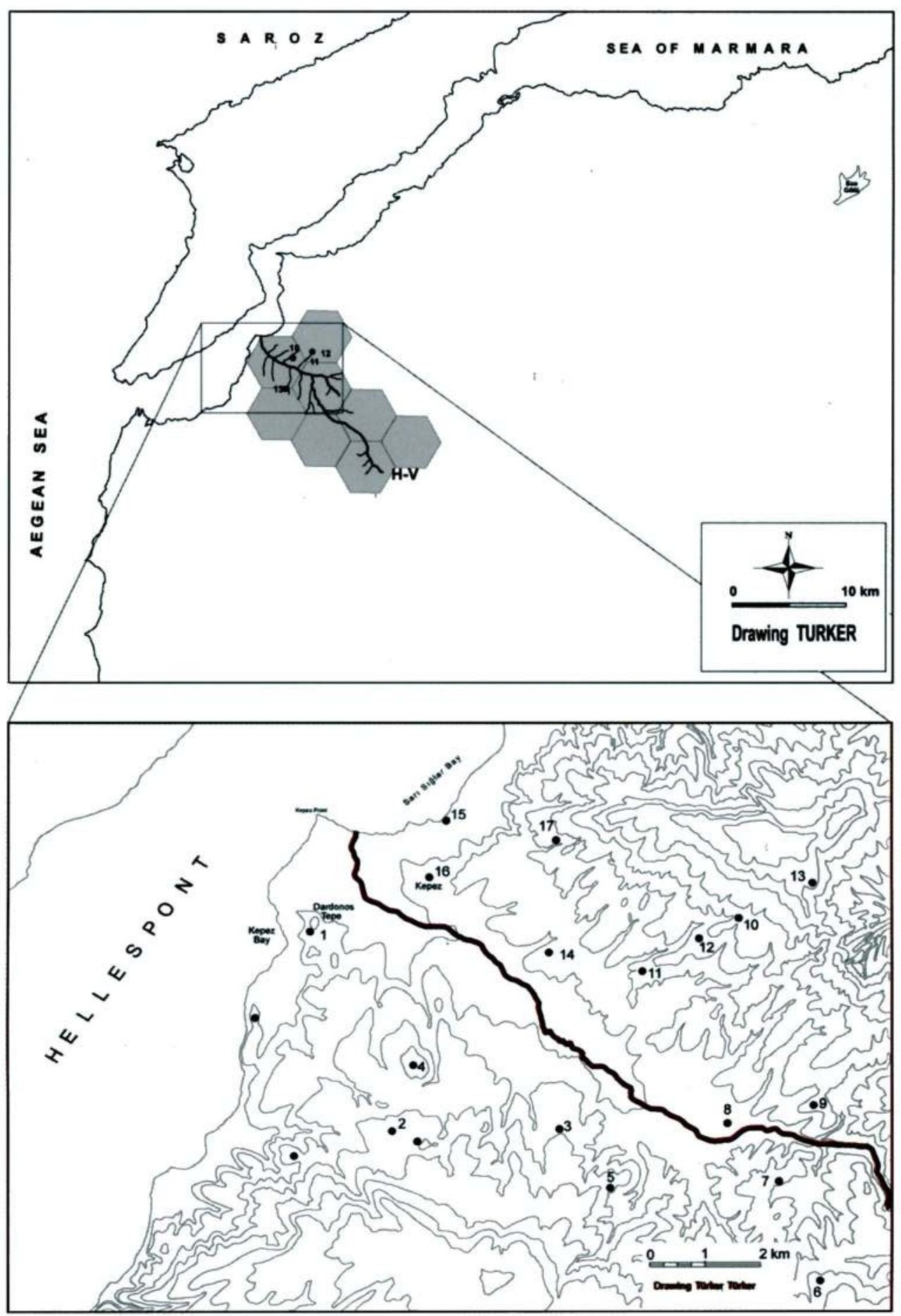

Figure 1. Byzantine finding areas in Kalabakh Valley (Drawing Türker Türker) 
Ayşe C.. Türker

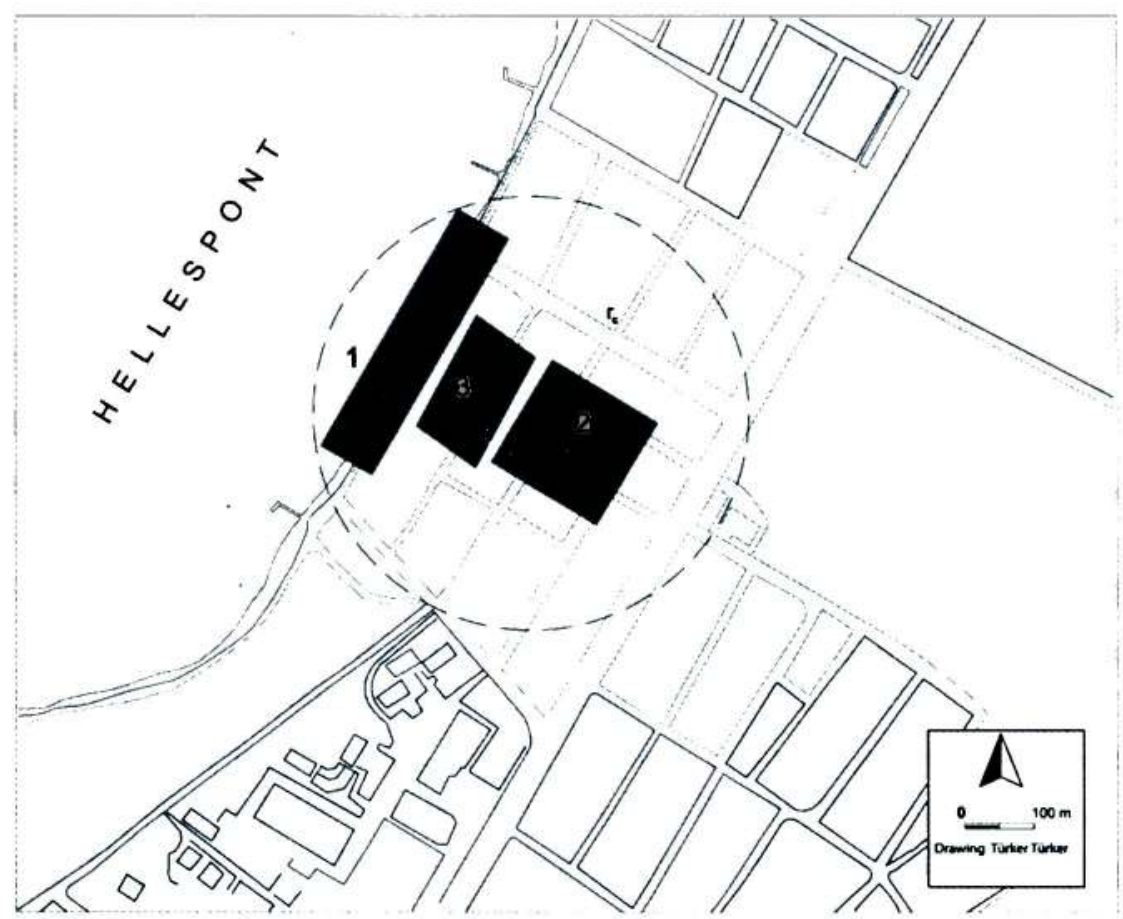

Figure 2. Finding areas of the pottery in Kepez (Drawing Türker Türker)

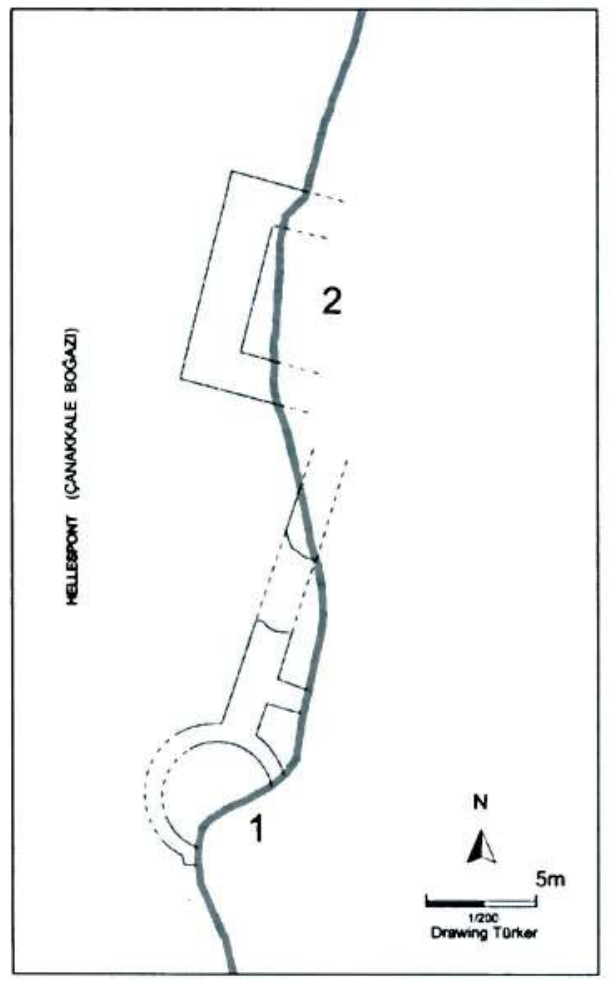

Figure 3. A scaled sketch of the architectural ruin on the Sarisiglar coast of Kepez (Drawing Türker Türker) 
Ayşe Ç. Türker

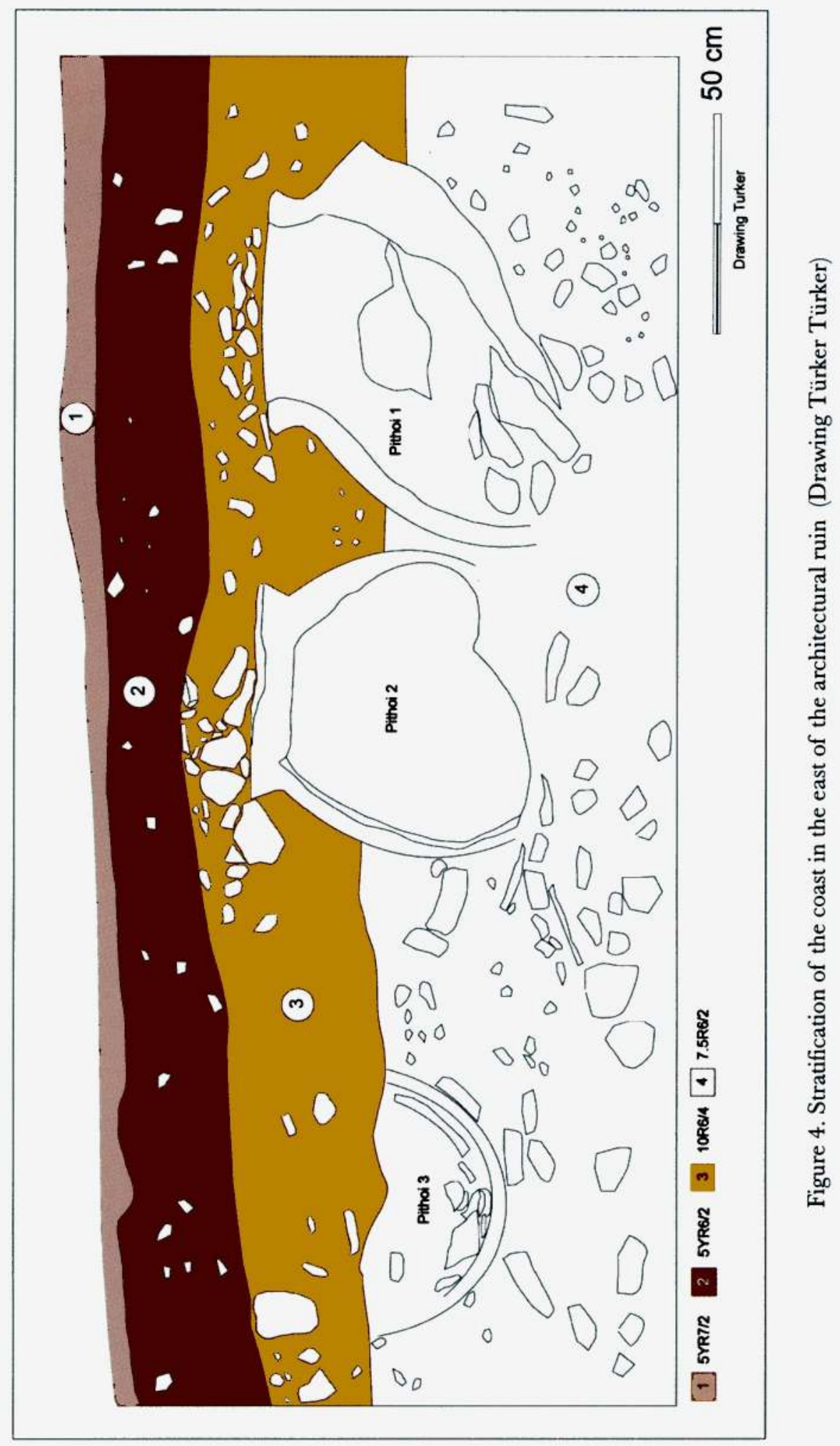


Ayșe Ç. Türker
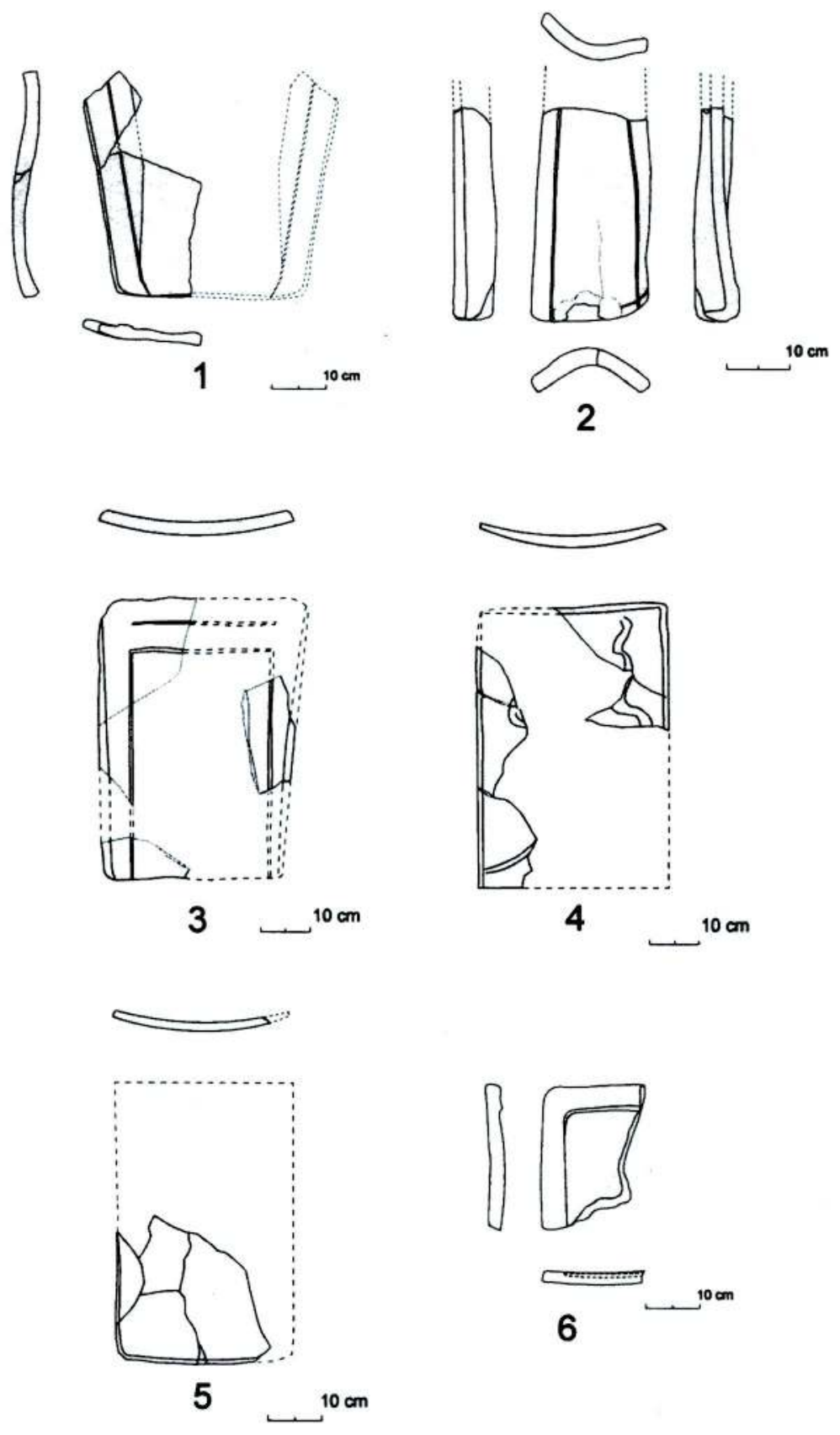

Figure 5. Tiles from Kepez (Drawing Türker Türker) 

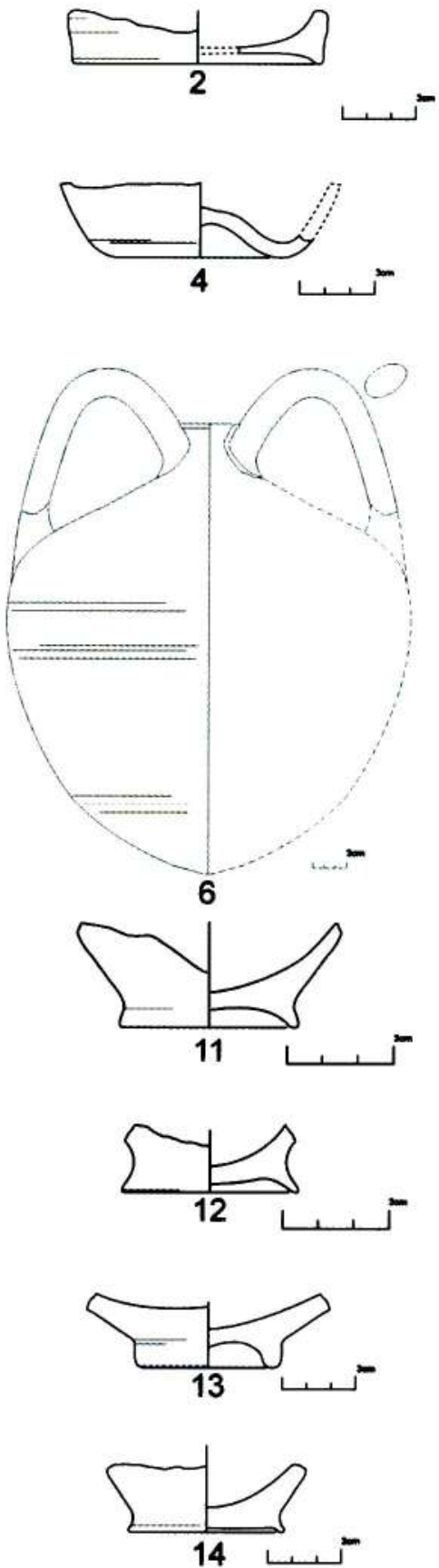
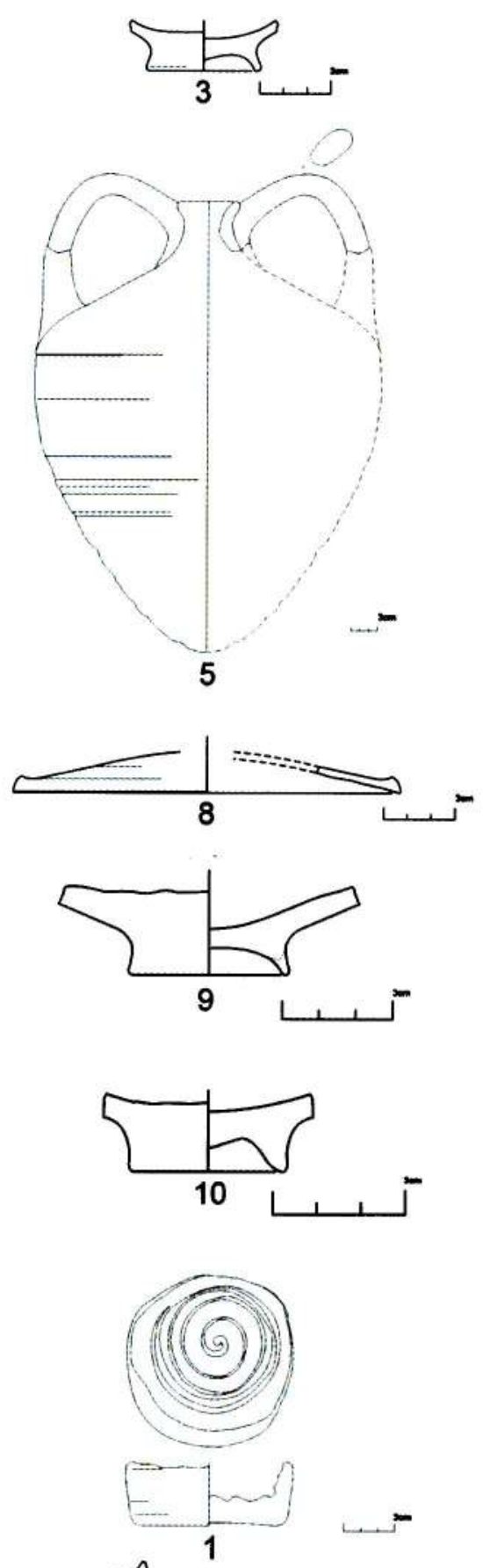

Drawing Turker

Figure 6. Pottery from Kepez 


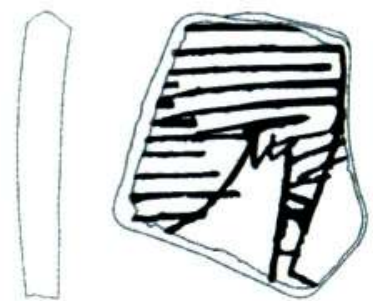

16
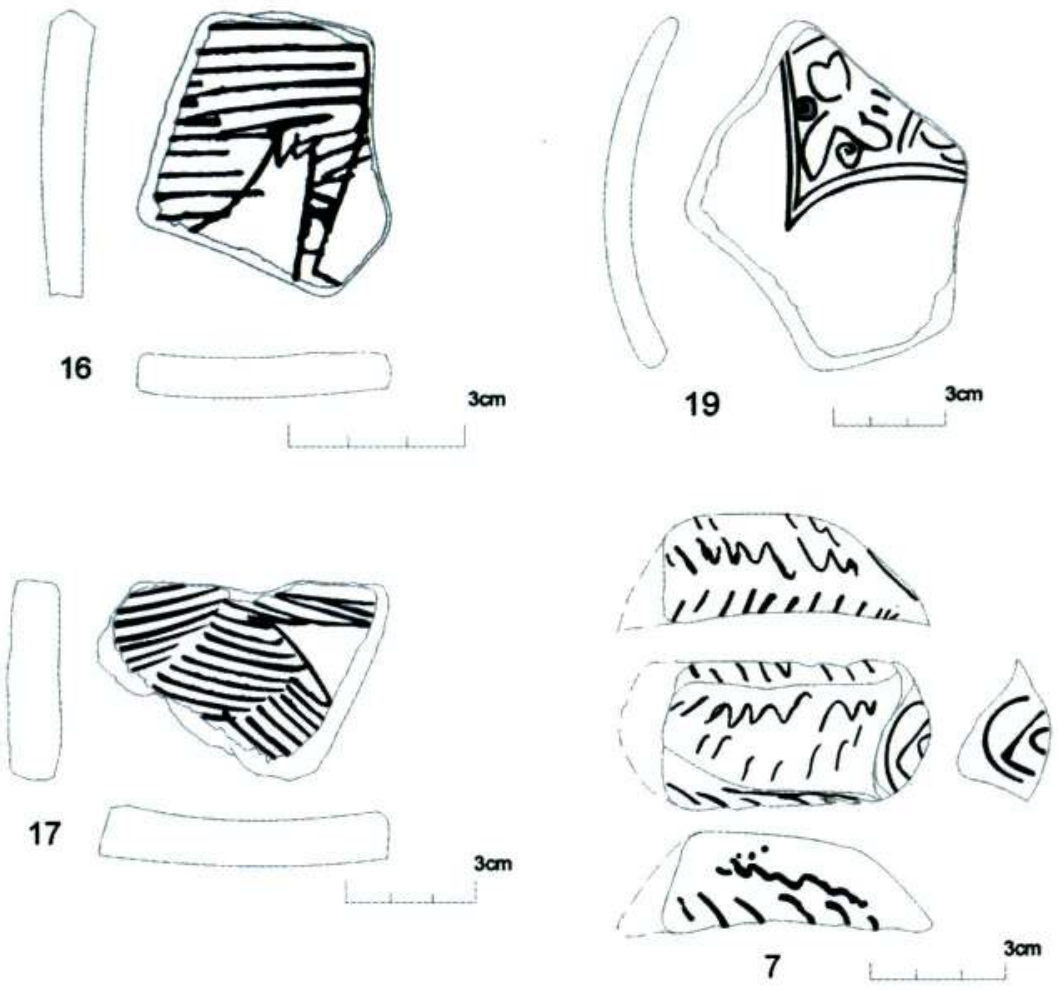

Figure 7. Pottery from Kepez (Drawing Türker Türker) 


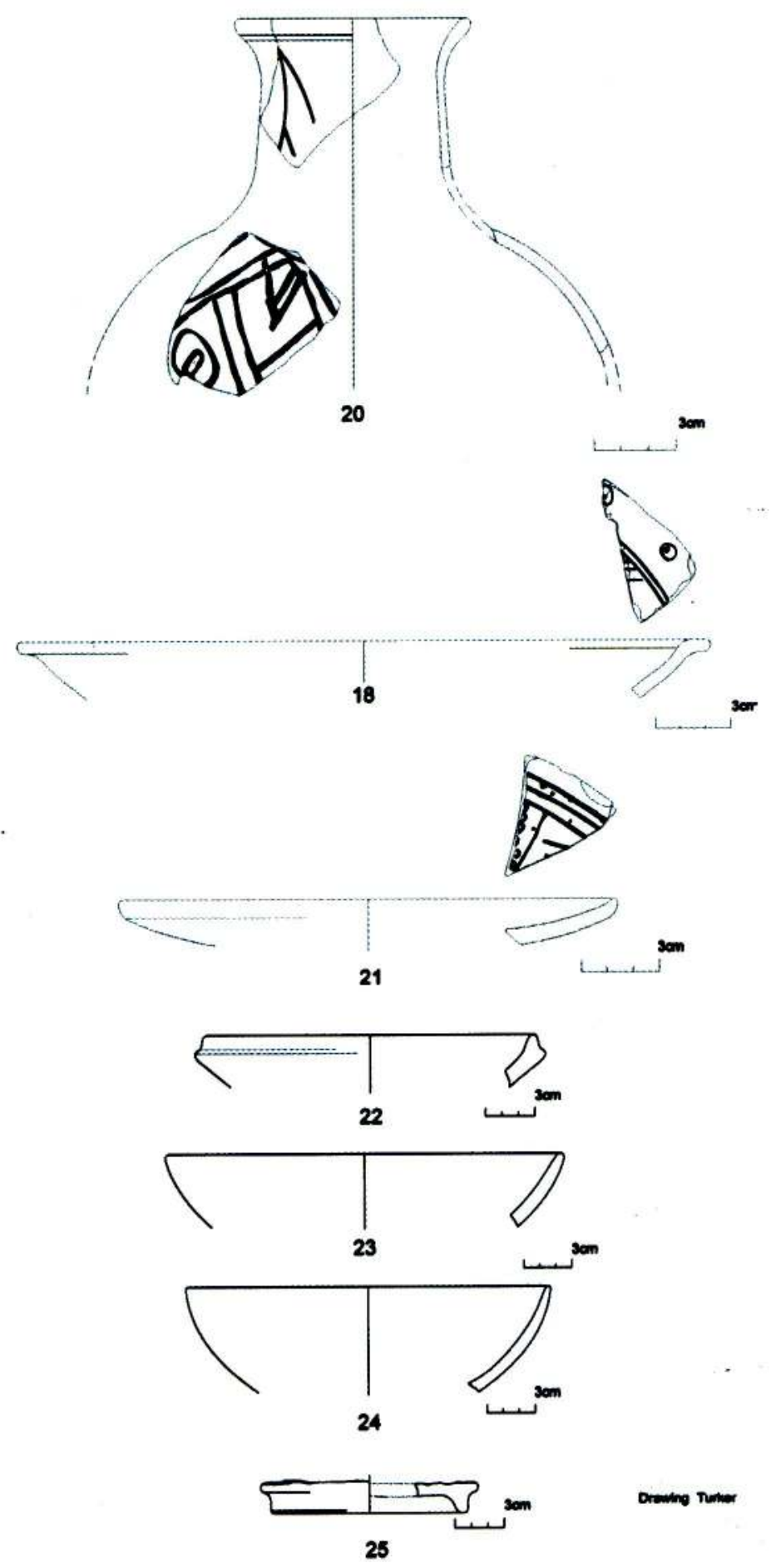

Figure 8. Pottery from Kepez (Drawing Türker Türker) 

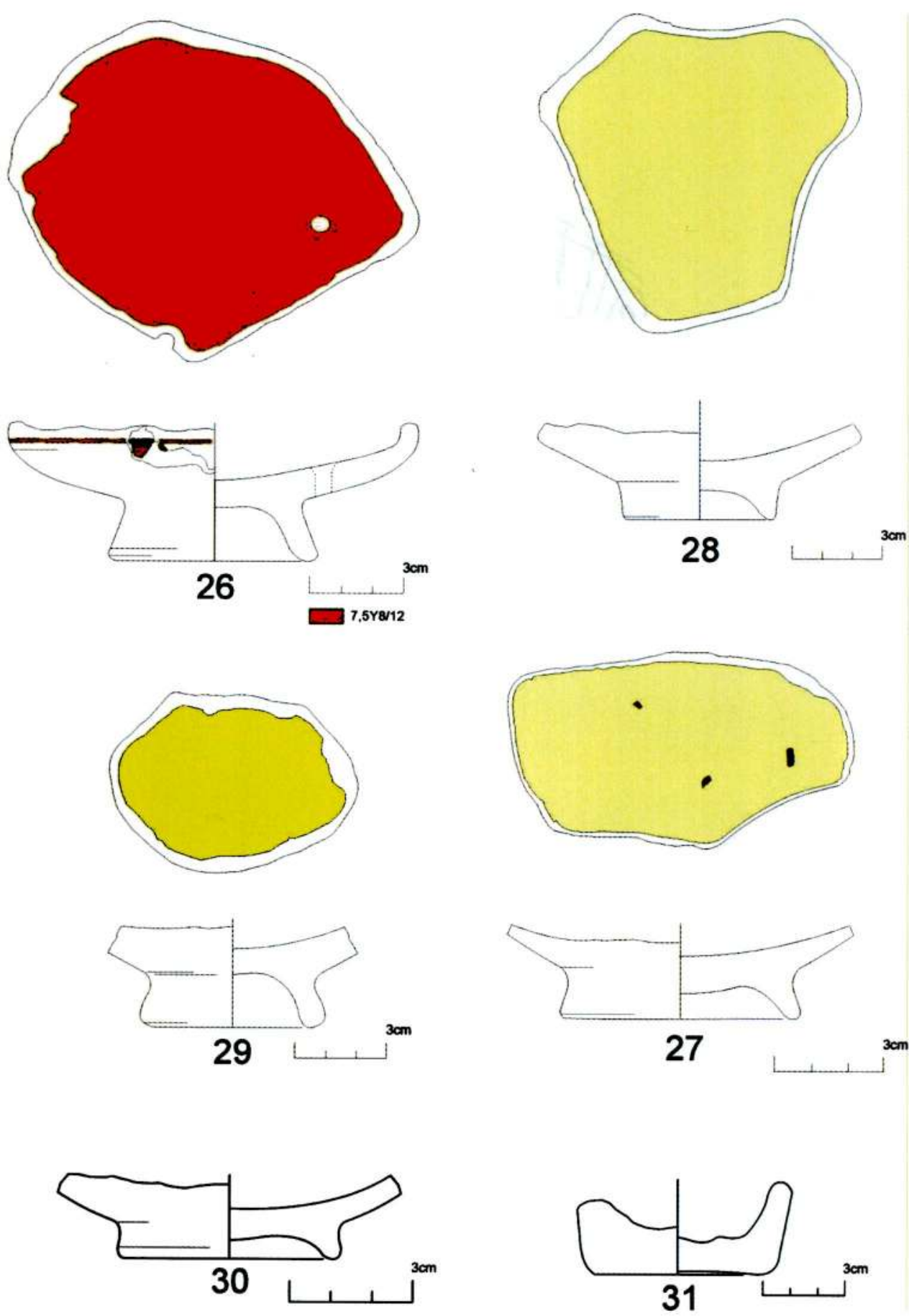

Figure 9. Pottery from Kepez (Drawing Türker Türker) 
Ayşe Ç. Türker

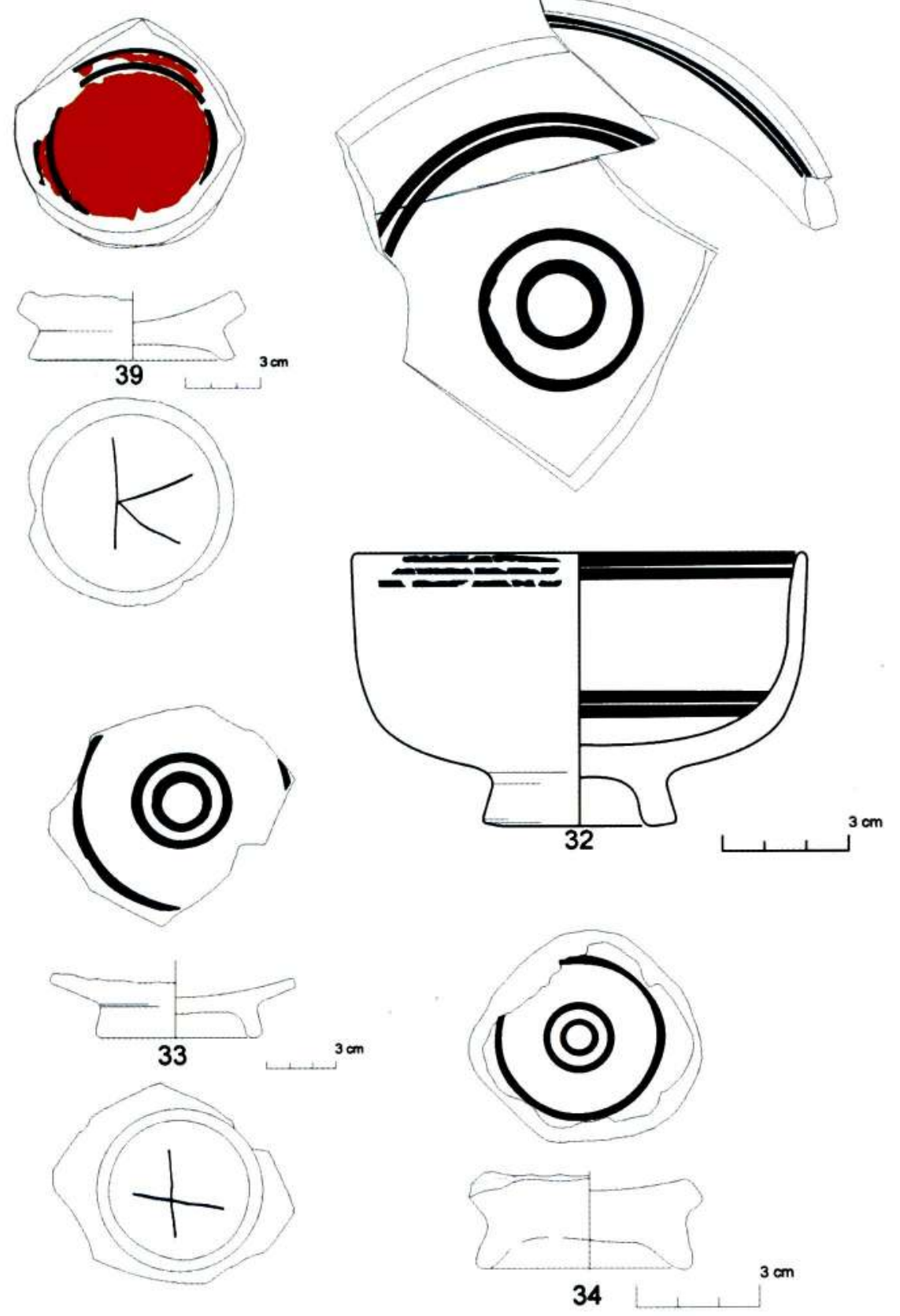

Figure 10. Pottery from Kepez (Drawing Türker Türker) 
Ayșe Ç. Türker

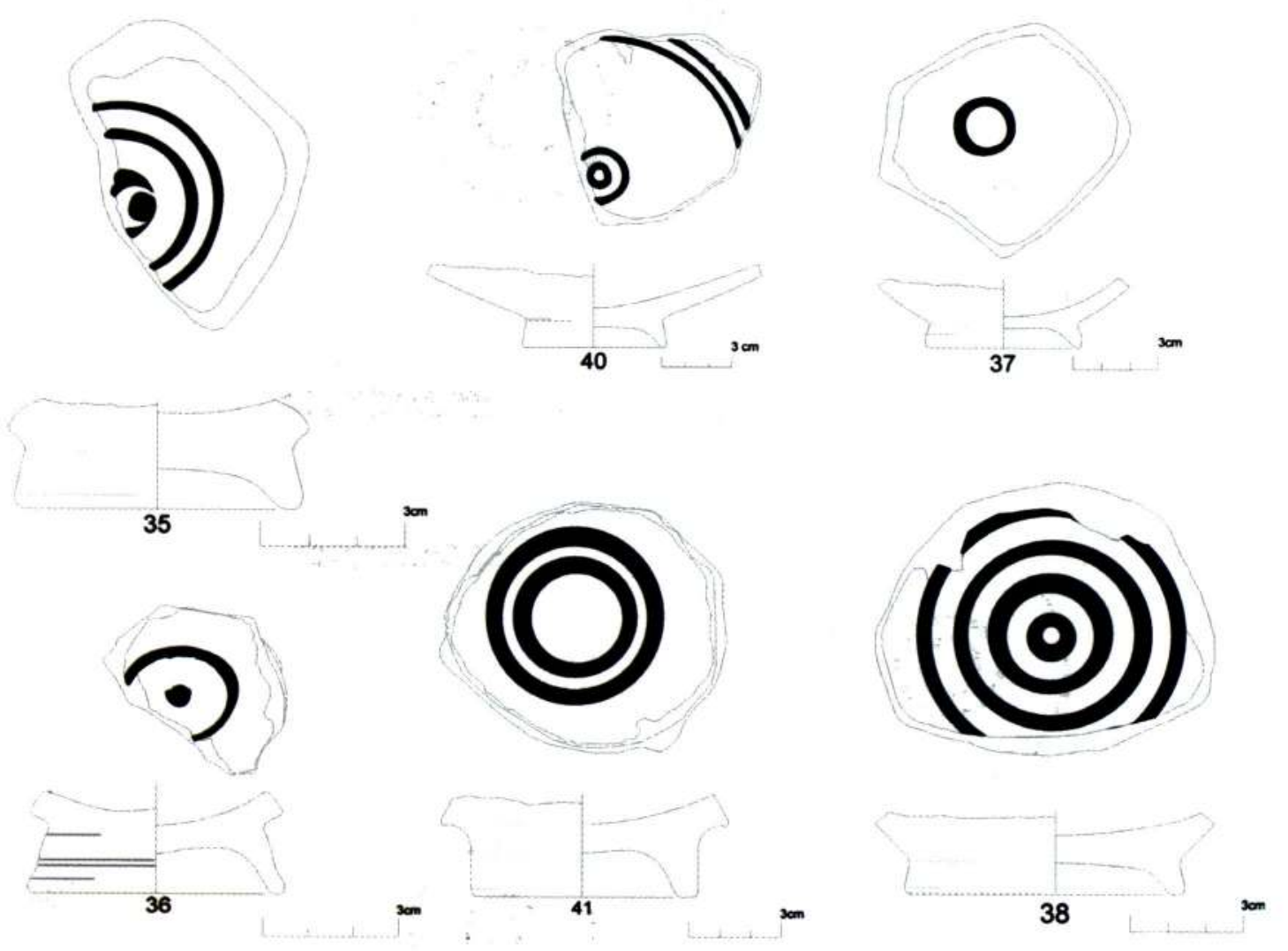

Figure 11. Pottery from Kepez (Drawing Türker Türker) 

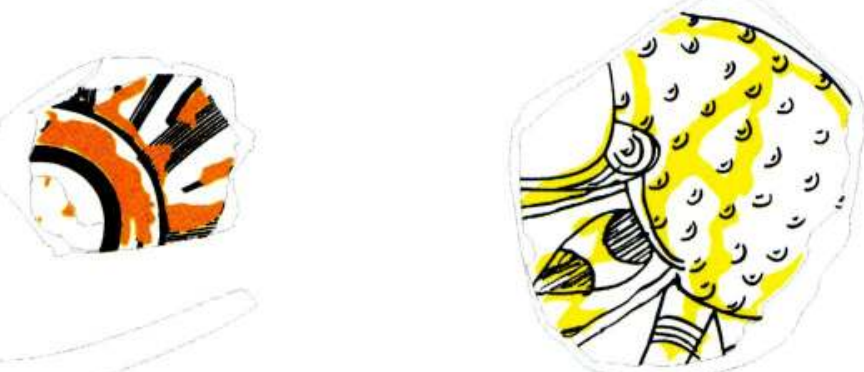

43

$3 \mathrm{~cm}$

48 $3 \mathrm{~cm}$

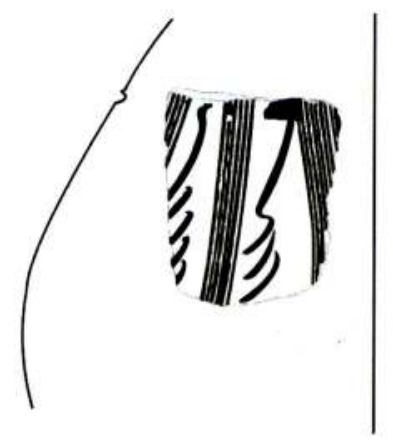

हैं (1)

47

44

$3 \mathrm{~cm}$

$3 \mathrm{~cm}$

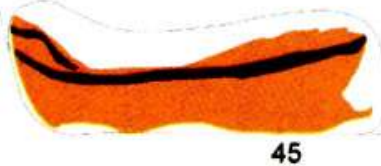

$3 \mathrm{~cm}$

Figure 12. Pottery from Kepez (Drawing Türker Türker) 
Aysse C.. Türker
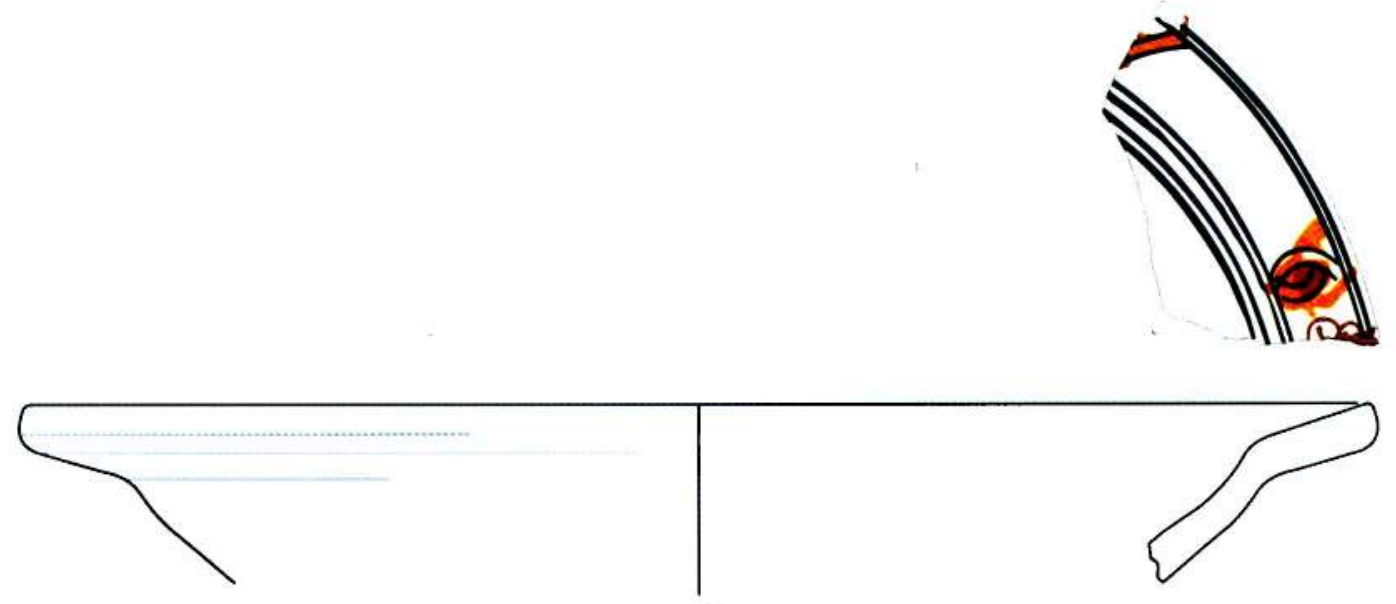

46

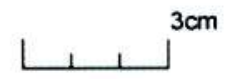

42

$3 \mathrm{~cm}$

Figure 13. Pottery from Kepez (Drawing Türker Türker) 


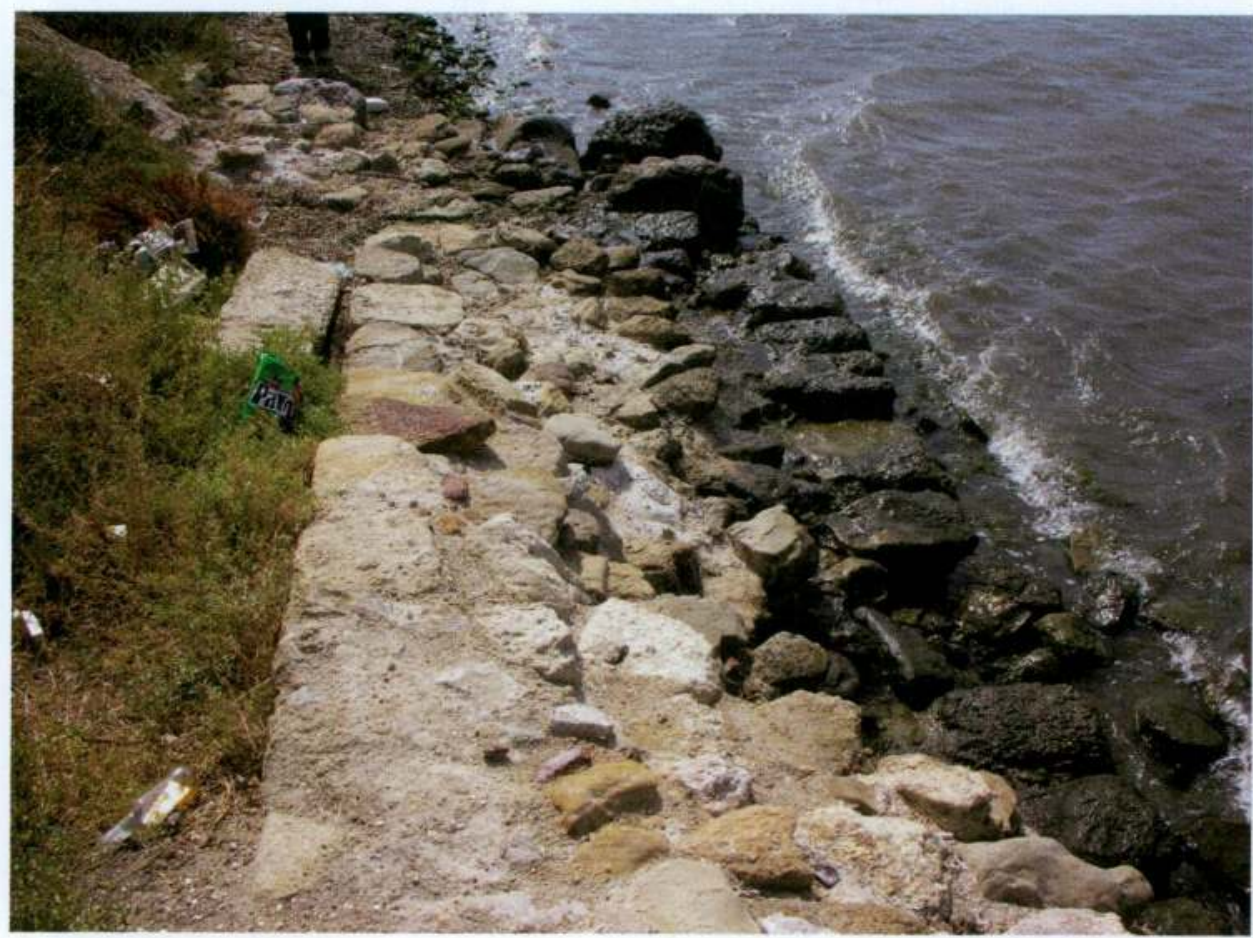

Figure 14. The architectural ruin on the Sarisiglar coast of Kepez

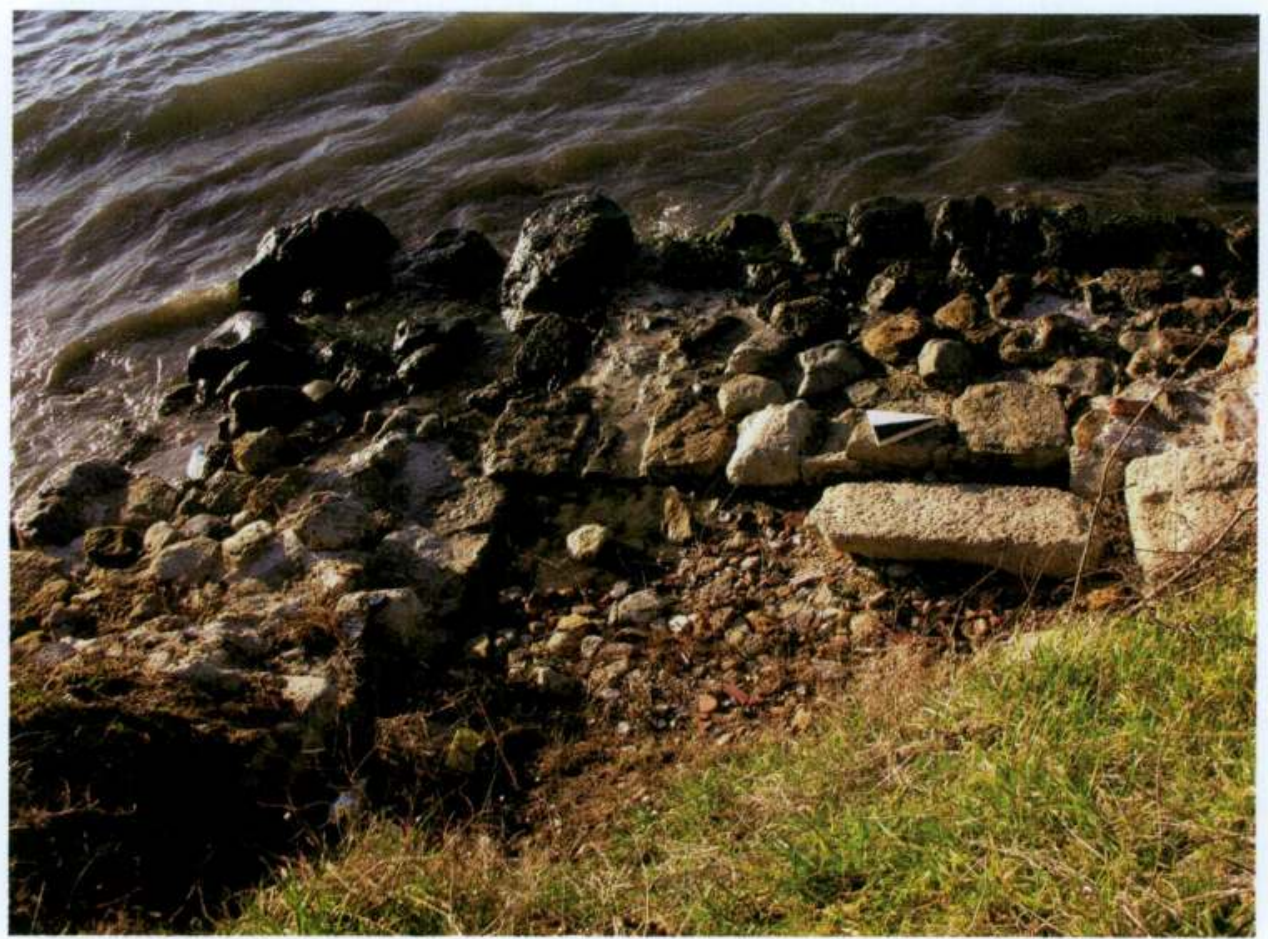

Figure 15. The architectural ruin on the Sarisiglar coast of Kepez 


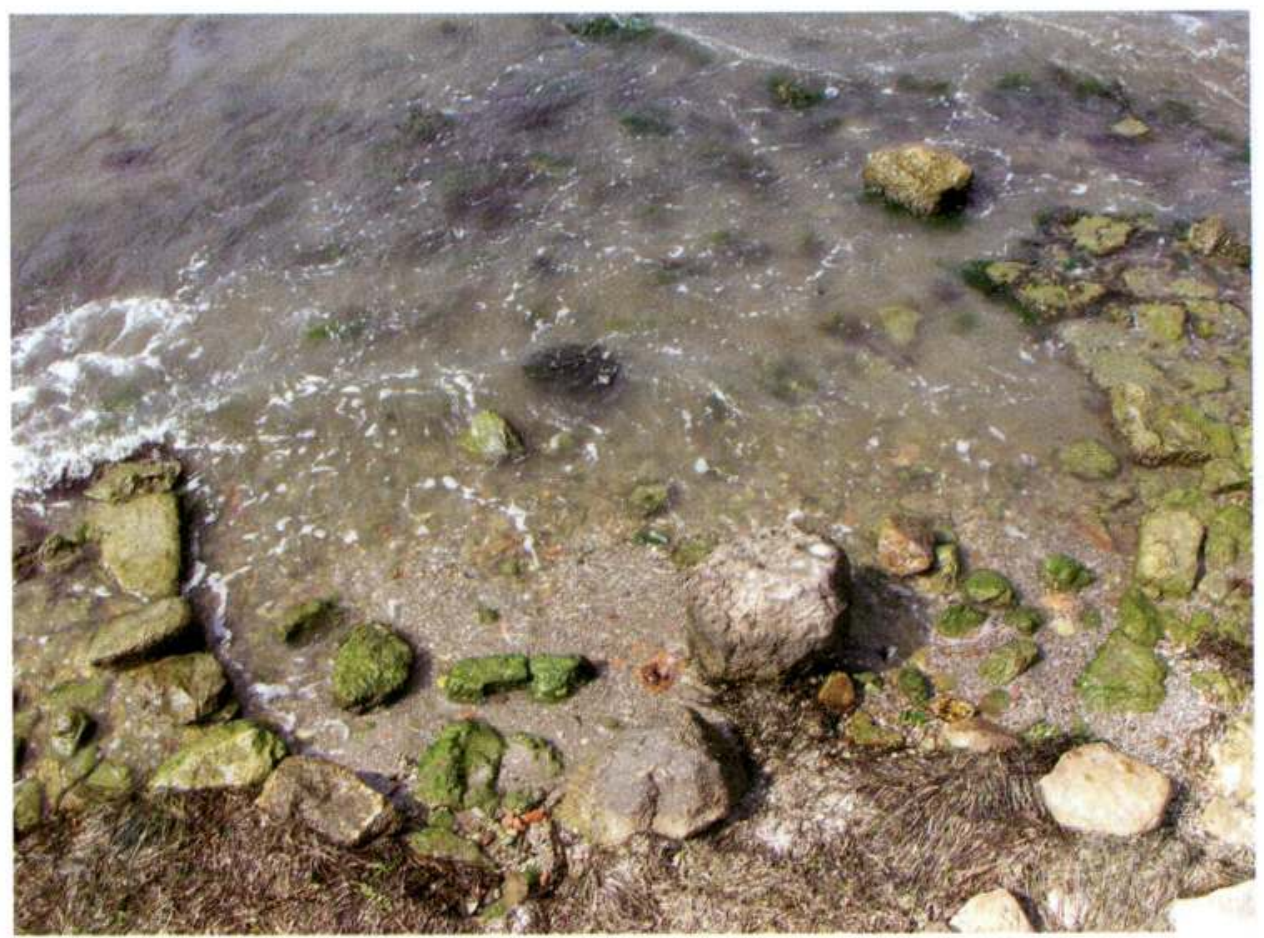

Figure 16. The architectural ruin on the Sarisiglar coast of Kepez

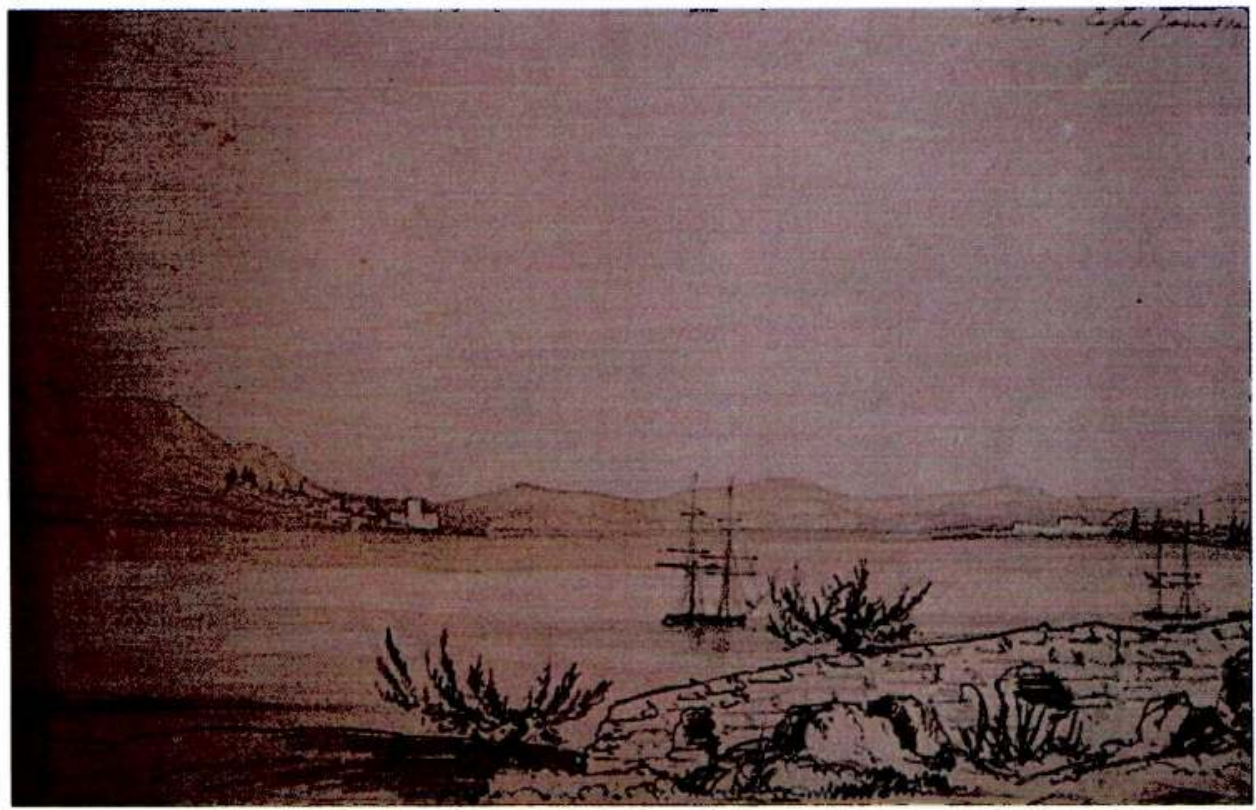

Figure 17. The description in the Searight Collection 


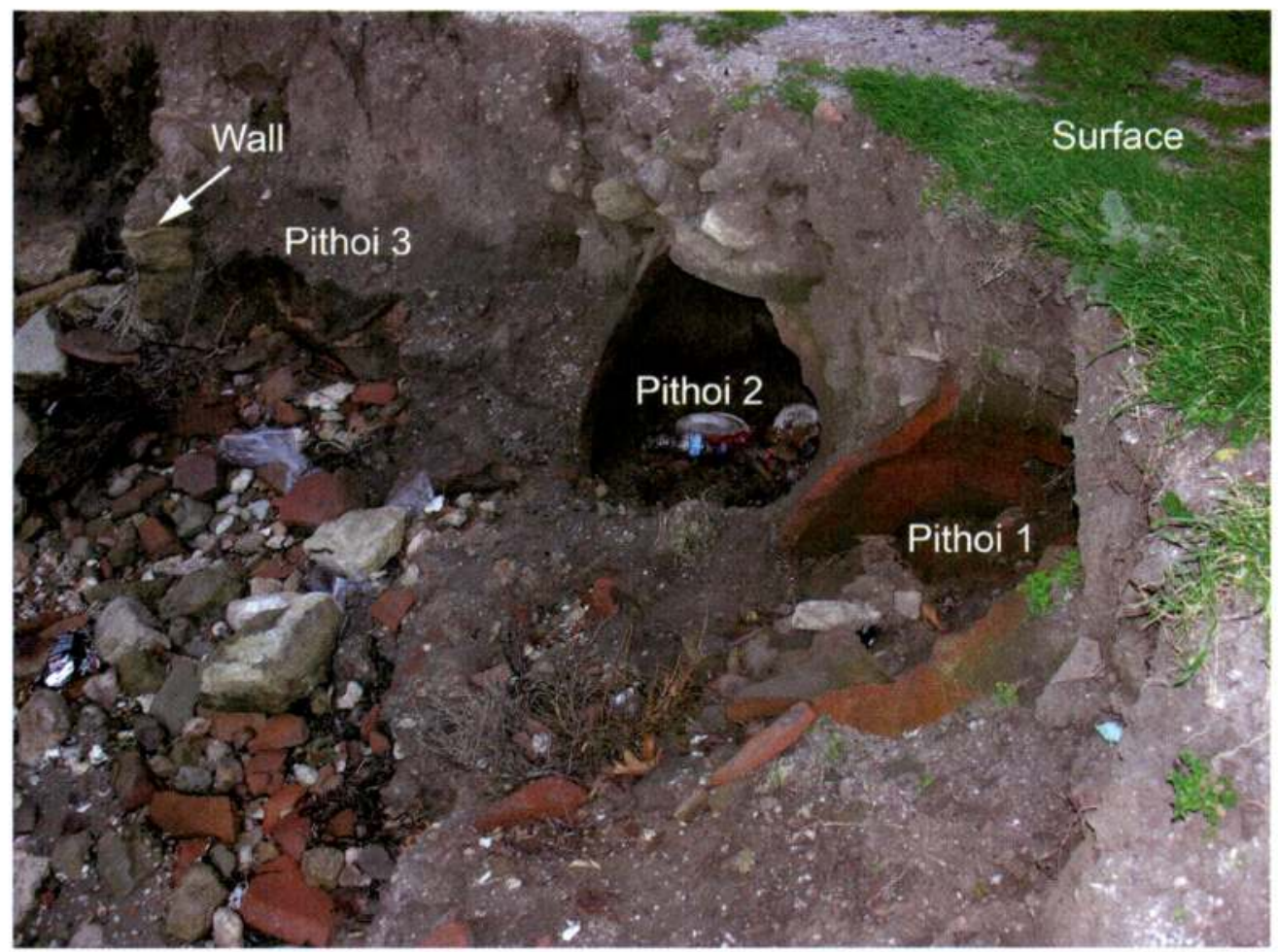

Figure 18. Pithoi in the east of the architectural ruin
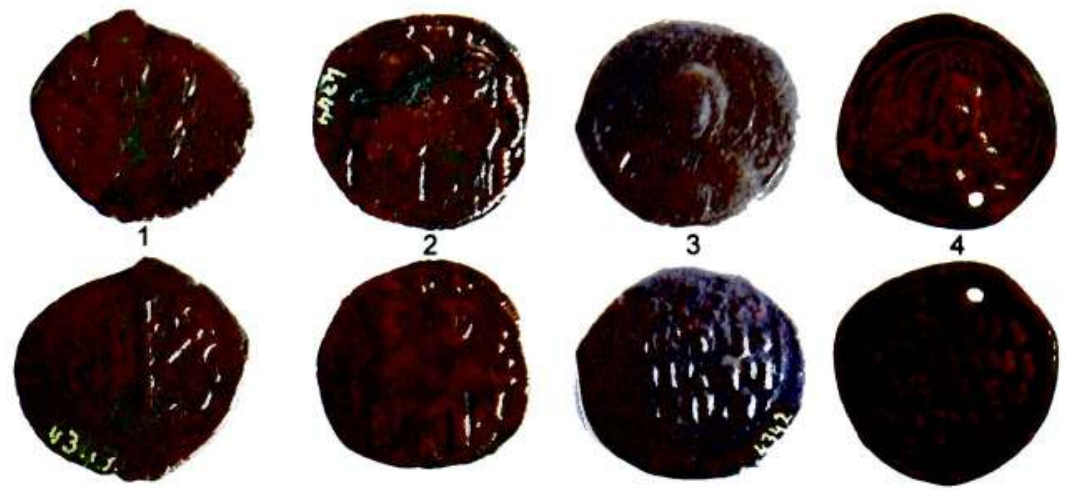

Figure 19. Byzantine coins from Kepez in the Çanakkale Archaeology Museum 
Aysse C.. Türker

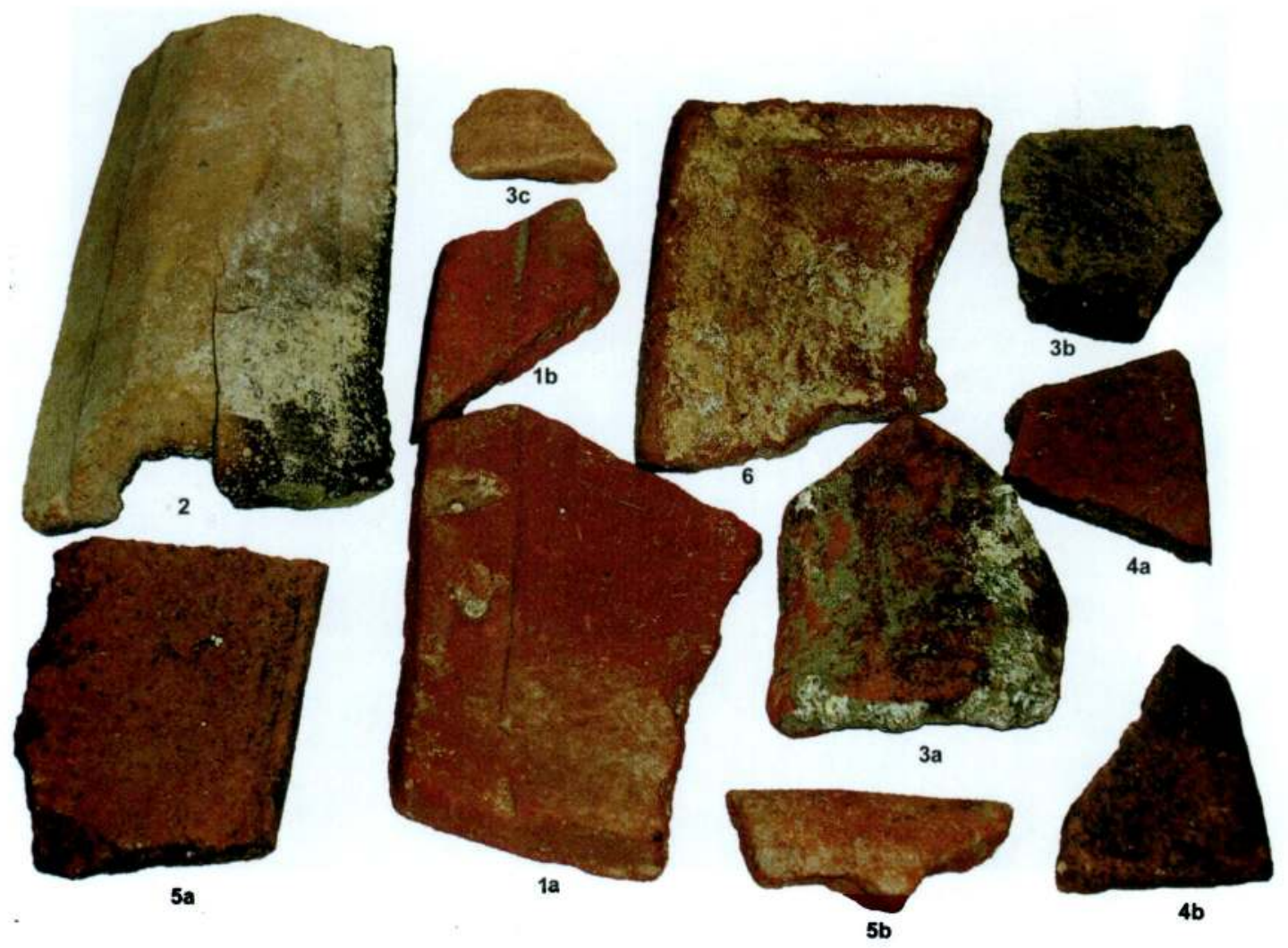

Figure 20. Tiles from Kepez 
Aysse C.. Türker

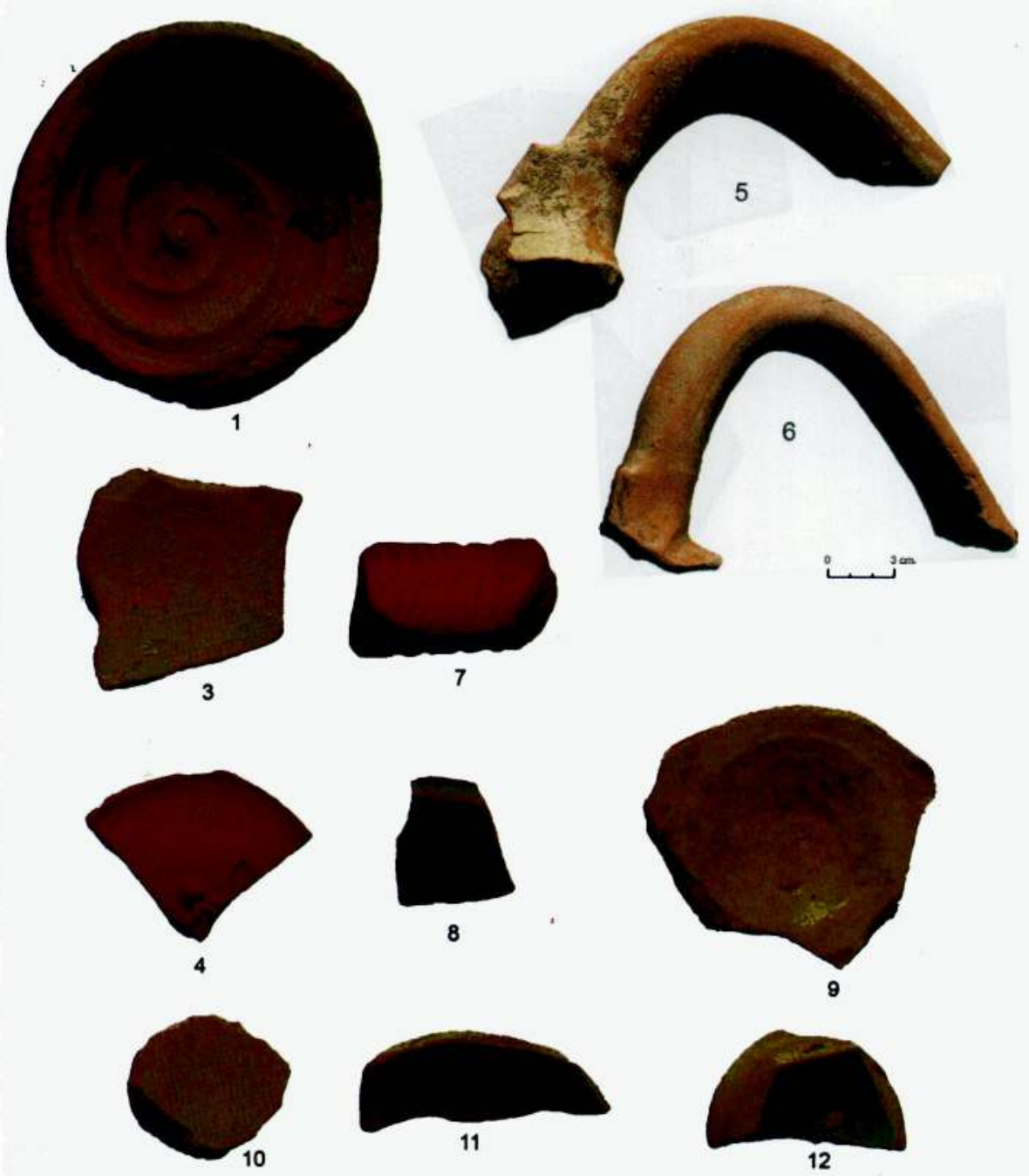

Figure 21. Pottery from Kepez 

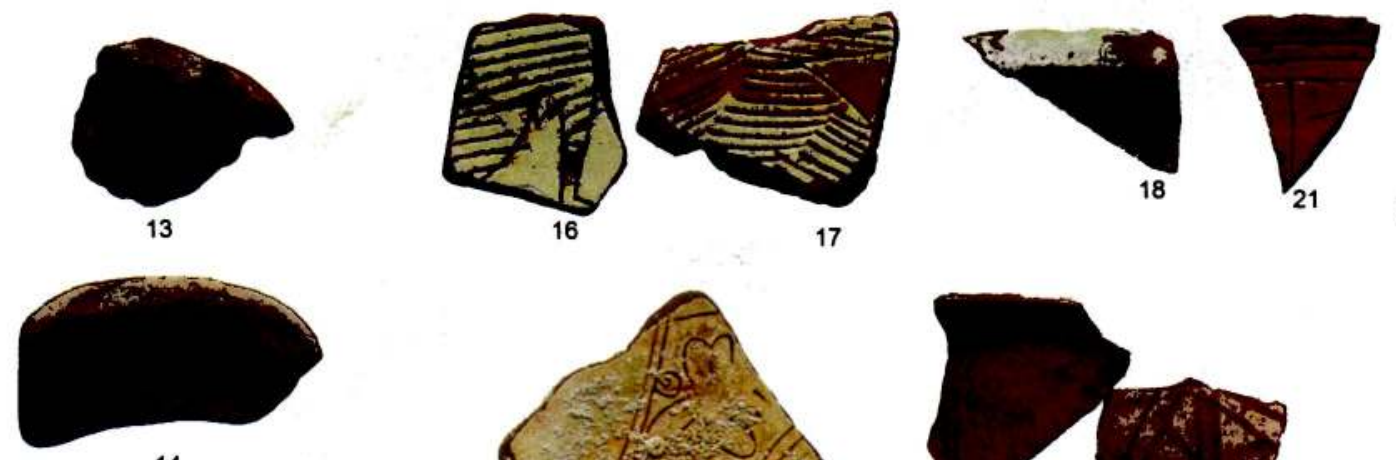

14
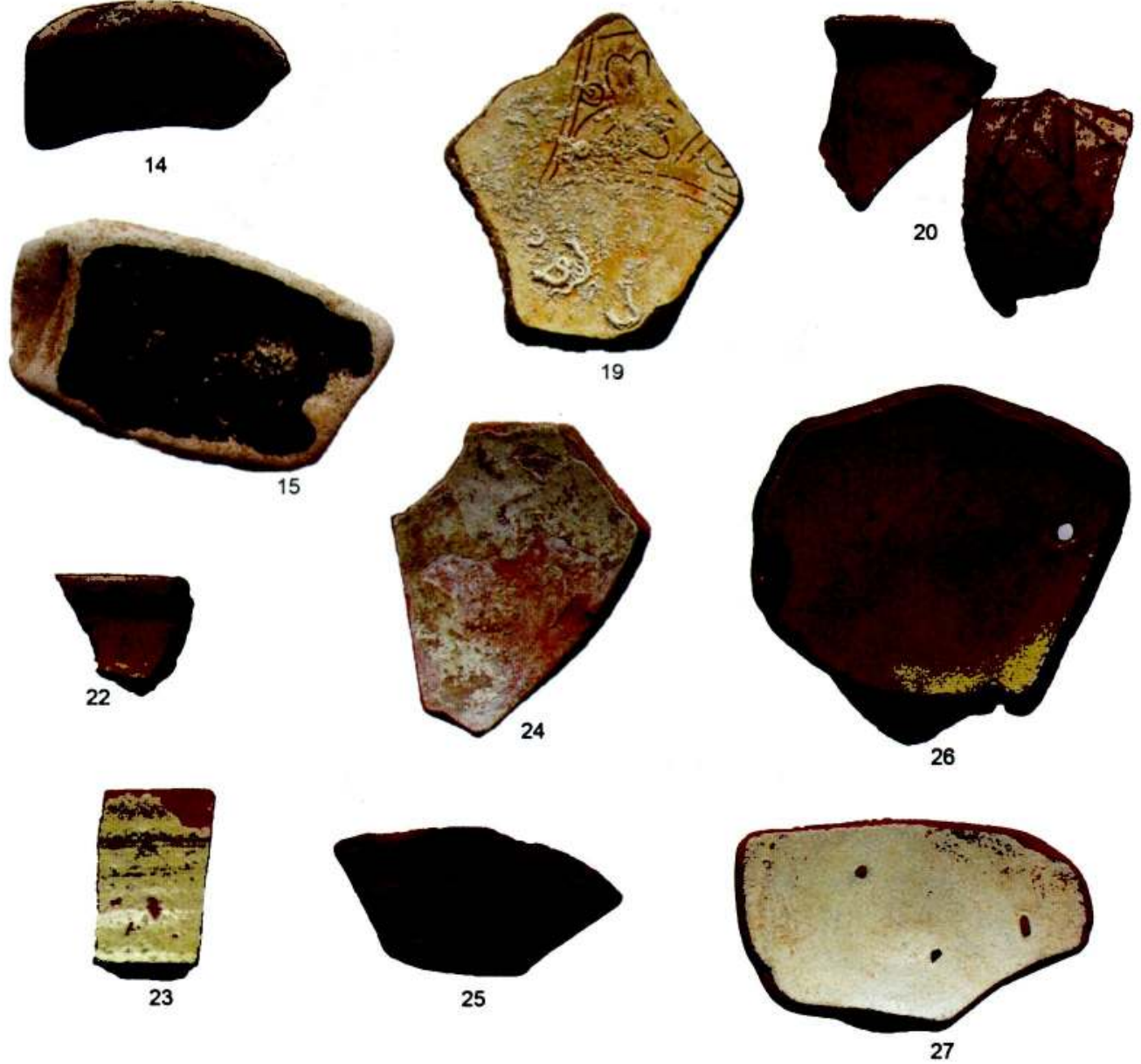

Figure 22. Pottery from Kepez 

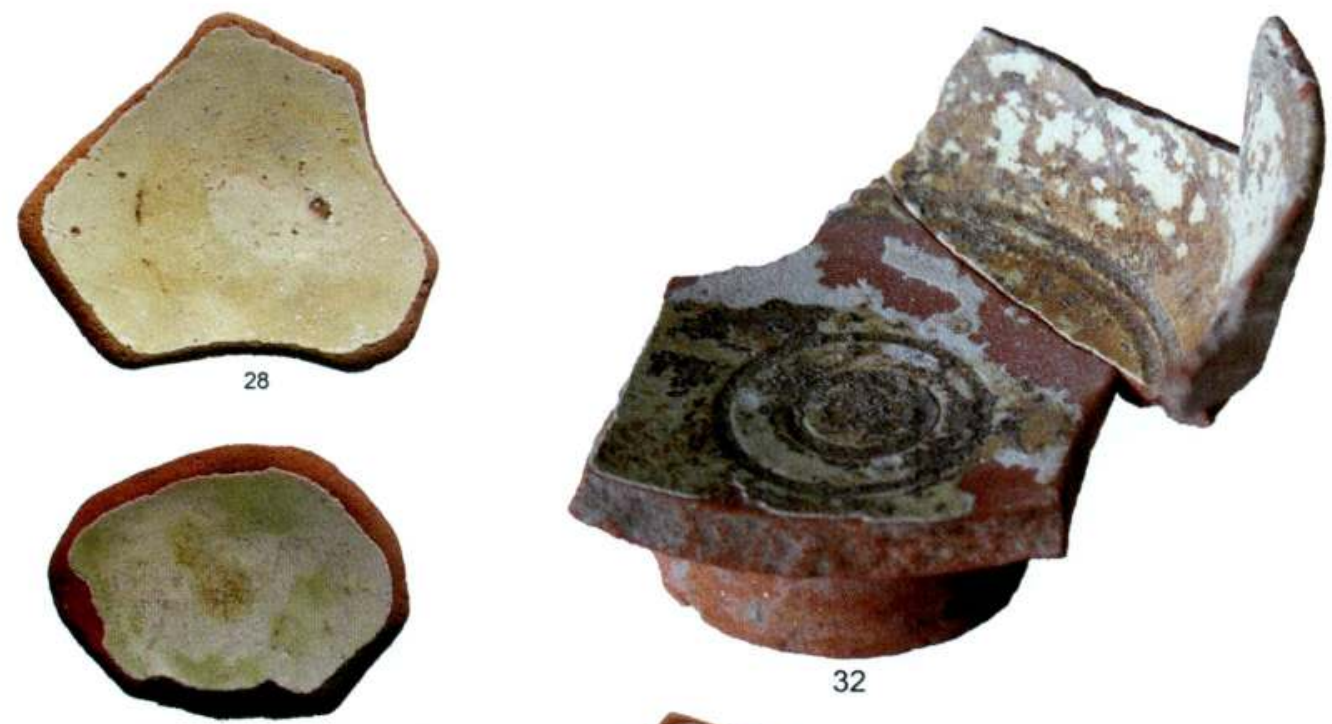

29
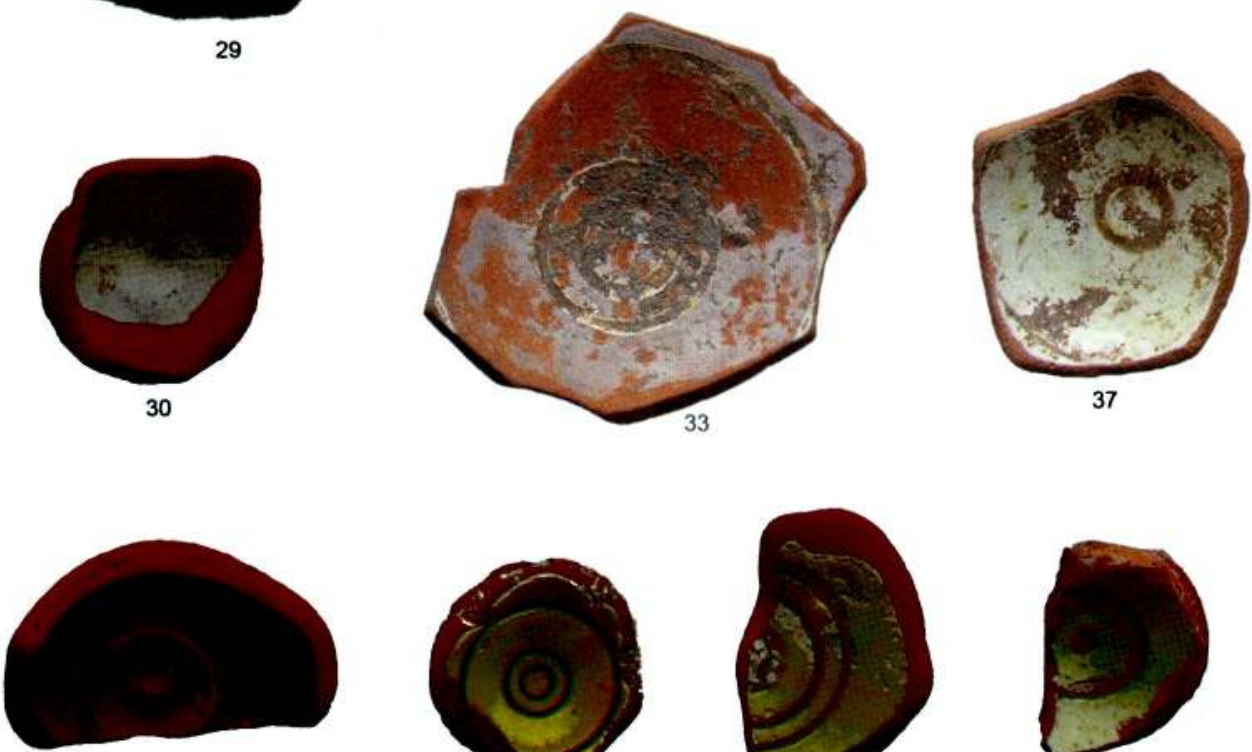

31
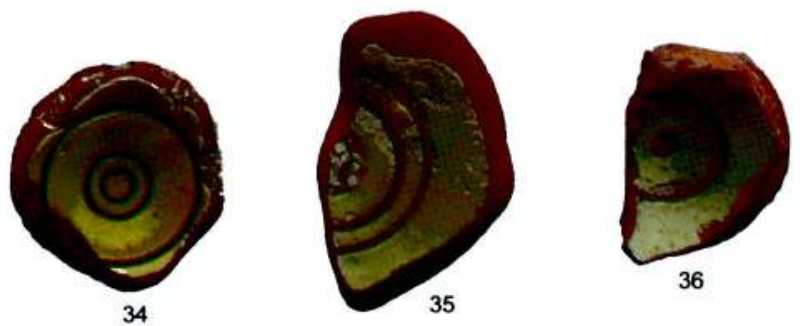

Figure 23. Pottery from Kepez 
Ayşe Ç. Türker
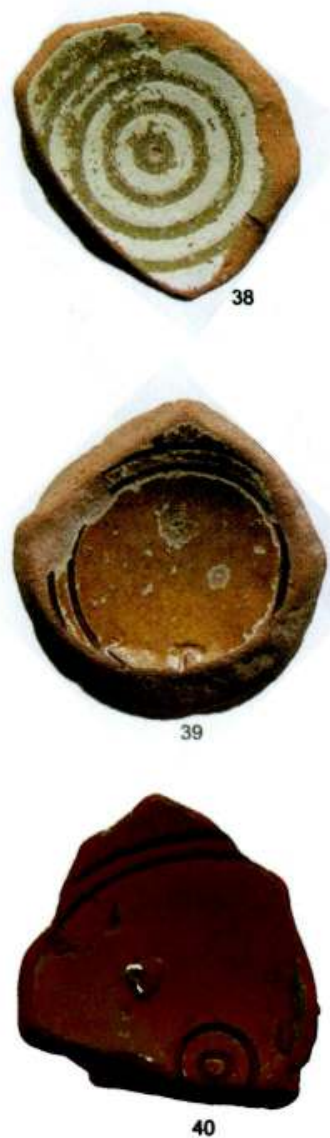
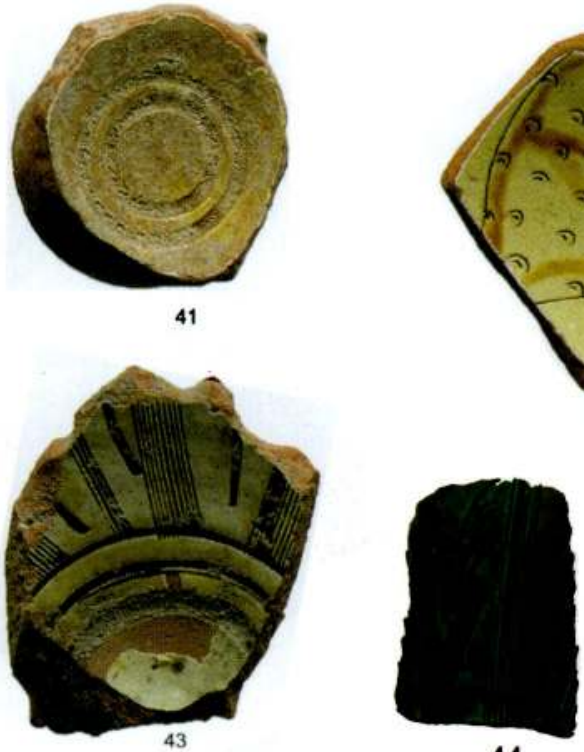

44
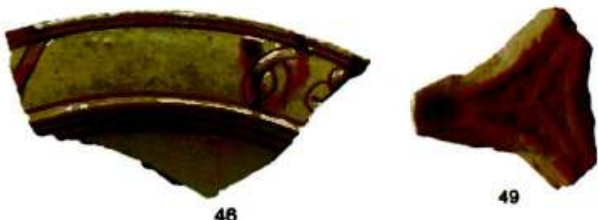

Figure 24. Pottery from Kepez 